\title{
Harnessing the Potential of Stem Cells for Disease Modeling: Progress and Promises
}

\author{
Chiara Argentati ${ }^{1, \dagger}$, Ilaria Tortorella ${ }^{1, \dagger}$, Martina Bazzucchi ${ }^{1}$, Francesco Morena ${ }^{1}$ \\ and Sabata Martino 1,2,* \\ 1 Department of Chemistry, Biology and Biotechnologies, University of Perugia, Via del Giochetto, \\ 06126 Perugia, Italy; chiara.argentati89@gmail.com (C.A.); tortorella.i@hotmail.it (I.T.); \\ martina.bazzucchi89@gmail.com (M.B.); francesco.morena@unipg.it (F.M.) \\ 2 CEMIN, Center of Excellence on Nanostructured Innovative Materials, Via del Giochetto, 06126 Perugia, Italy \\ * Correspondence: sabata.martino@unipg.it; Tel.: +39-075-585-7442 \\ + These authors contributed equally to this work.
}

Received: 12 December 2019; Accepted: 1 February 2020; Published: 6 February 2020

\begin{abstract}
Ex vivo cell/tissue-based models are an essential step in the workflow of pathophysiology studies, assay development, disease modeling, drug discovery, and development of personalized therapeutic strategies. For these purposes, both scientific and pharmaceutical research have adopted ex vivo stem cell models because of their better predictive power. As matter of a fact, the advancing in isolation and in vitro expansion protocols for culturing autologous human stem cells, and the standardization of methods for generating patient-derived induced pluripotent stem cells has made feasible to generate and investigate human cellular disease models with even greater speed and efficiency. Furthermore, the potential of stem cells on generating more complex systems, such as scaffold-cell models, organoids, or organ-on-a-chip, allowed to overcome the limitations of the two-dimensional culture systems as well as to better mimic tissues structures and functions. Finally, the advent of genome-editing/gene therapy technologies had a great impact on the generation of more proficient stem cell-disease models and on establishing an effective therapeutic treatment. In this review, we discuss important breakthroughs of stem cell-based models highlighting current directions, advantages, and limitations and point out the need to combine experimental biology with computational tools able to describe complex biological systems and deliver results or predictions in the context of personalized medicine.
\end{abstract}

Keywords: organoids; organ-on-a-chip; iPSCs; gene therapy; genome editing; tissue engineering; computational cell modeling

\section{Introduction}

Over the past decades, much of our understanding of human physiology and pathologies has been derived from studies on animal models. However, during the years, emerging limitations have raised doubts about the reliability of this investigational approach [1]. The main criticisms about the actual predictive value of animal models are related to (i) their limits on fully recapitulating the human physiology/pathologies (e.g., different pharmacokinetics and toxicokinetic; presence of alternative pathways that may interfere with the progression of a given disease; different immune-response), (ii) their maintenance costs, and (iii) the ethical issues associated with their use [2-4]. Thus, even if animal models, especially mammals, are still an essential tool before a novel therapeutic strategy enters clinical trials, their use is severely restricted [5]. In order to overcome these limitations, scientists have focused on finding alternative approaches and tools that could recapitulate the homeostasis of 
cells/tissues as well as pathological alterations. Therefore, in vitro cell/tissue models today became a very promising tool for investigating human development, physiology and disease pathogenesis.

Here, we review the progress made in establishing the most proficient cell/tissue modeling, from basic cell culture systems to more innovative organoid platforms.

\section{Cell Modeling Overview: From Basic 2D-Cultures to 3D-Innovative Systems}

Since their establishment, cell cultures have been proven to be the first and most powerful tool for the in vitro investigation of cell biology, from basic research to more complex translational approaches [6]. Classical two-dimensional (2D)-cultures usually consist of a unique type of cells (primary or continuous cultures) that grow in tissue culture polystyrene as adherent monolayers or in floating suspension, both in culture media that provide essential nutrients and growth factors. 2D-strategies are widely used to obtain a large number of cells, thus allowing the in vitro study of molecular mechanisms and development of metabolic assays [7-9]. However, due to their inability to recreate the in vivo complexity of the biological environment, they are not suitable for accurate disease modeling. These limitations have been overcome by the development of three-dimensional (3D)-cell cultures systems [10]. The rationale design of 3D-cell cultures is to harvest cells in microstructures that resemble tissues or organs shape and organization, thus allowing better cell-to-cell/cell-environment contacts and signaling crosstalk [11-15], essential events for tissues correct development and functioning [14,15]. The 3D-cell culture strategy is articulated in many different methods and techniques that can be grouped in scaffold-based or non-scaffold based platforms, each with particular advantages and disadvantages that make them useful for different applications [10,16-19]. 3D-cell culture strategies are supported by the in silico modeling of multicellular systems that requires sophisticated techniques that go beyond the standard model formalisms in systems biology and allows complicated geometrical constructions $[20,21]$. In this regard, many computational tools allow predicting the more proficient cell model. These methods enable formulating both compartmental and spatial models with either 2Dor 3D-geometries, theoretically- or experimentally-derived. Several modeler environments have been developed in order to simulate and incorporate cell-based models, to describe the interactions and dynamics of cell-bound variables and to define molecular species in reaction-diffusion systems [22-32]. These computational tools allow simulating a wide range of cellular phenomena in space and time, both deterministically and stochastically (Table 1).

All of the above-mentioned techniques have been developed to respond to the compelling need to find better preclinical models for the study and modeling of disease pathogenesis.

Table 1. List of modeler environments software.

\begin{tabular}{cccc}
\hline Software & Application & Link & Ref. \\
\hline BIOCHAM4 & $\begin{array}{c}\text { A software environment for modeling } \\
\text { biochemical systems }\end{array}$ & https://lifeware.inria.fr/biocham4/ & [22] \\
Bio-SPICE & $\begin{array}{c}\text { Biological simulation software for intra- and } \\
\text { inter-cellular evaluation, modeling and simulation } \\
\text { of spatio-temporal processes in living cells }\end{array}$ & http://biospice.sourceforge.net & [23] \\
\hline $\begin{array}{c}\text { CellML allows scientists to store and share } \\
\text { computer-based mathematical models }\end{array}$ & https://www.cellml.org \\
Biochemical & $\begin{array}{c}\text { A software application for simulation and analysis } \\
\text { of biochemical networks and their dynamics }\end{array}$ & http://copasi.org \\
\hline [24] & $\begin{array}{c}\text { A software platform for modeling, simulation and } \\
\text { analysis of complex, heterogeneous and multi-scale } \\
\text { E-Cell System }\end{array}$ & [25] \\
\hline
\end{tabular}


Table 1. Cont.

\begin{tabular}{|c|c|c|c|}
\hline Software & Application & Link & Ref. \\
\hline $\begin{array}{l}\text { Tissue Simulation } \\
\text { Toolkit }\end{array}$ & $\begin{array}{c}\text { A two-dimensional library for the Cellular Potts } \\
\text { Model to study tissue patterning and } \\
\text { developmental mechanisms }\end{array}$ & $\begin{array}{l}\text { https://biomodel.project.cwi.nl/ } \\
\text { software/software\#TST }\end{array}$ & [31] \\
\hline
\end{tabular}

\section{Ex Vivo Stem Cell-Based Modeling Systems}

Currently, stem cells (SCs) disease models represent the most powerful tool for having a better understanding of human disease pathogenesis and for developing new therapies [33]. As a matter of fact, the translation of stem cells intrinsic properties (i.e., self-renewal and pluri/multipotency) into an in vitro system allows the generation of selected cell lineages involved in the pathogenesis of a specific disease, along with promoting drug discovery, molecular screening, and transplantation therapies [33]. The first discoveries about SCs date back almost forty years when Evans and Kaufman isolated pluripotent cells from mouse embryos and established in vitro cultures of embryonic stem cells [34]. Since then, much research has been done in SCs field and today new stem cell-based disease models offer the possibility of personalizing the model according to the patient, observing a phenotype and then obtaining stem cells with the genotype of the donor subject, allowing to study also genetically complex disorders [35,36].

Among stem cell types, the most used for disease modeling purposes are adult stem cells (multipotent) [37] and induced pluripotent stem cells (iPSCs), because they permit the establishment of more advanced ex vivo models through: (i) Generation of committed/differentiated cell types involved in the disease; (ii) combination with biomaterials to generate a bio-hybrid system for tissue engineering applications; (iii) generation of organoids; and (iv) generation of organs-on-a-chip systems (Figure 1). Furthermore, the genome editing and gene therapy biotechnologies can be auxiliary tools to achieve the generation of more proficient stem cells disease models (Figure 1).

The advent of iPSCs opened a wide range of new stem cell applications. It is well-known that iPSCs can be derived from differentiated somatic cells, such as fibroblasts, by introducing defined transcriptional factors according to the Yamanaka and Takahashi protocol [38] and, like other pluripotent stem cells, have wide differentiation ability, giving rise to all cell derivatives of the three germ layers. As a matter of fact, the in vitro generation of iPSCs from somatic cells has made feasible the molecular study of different types of diseases, such as neurodegenerative diseases and cardiac diseases (see the list on Table 2), for which is difficult to obtain a tissue biopsy and autologous stem cells. For example, Israel et al. generated iPSCs from Sporadic Alzheimer's disease patients, demonstrating that they have high levels of Amyloid- $\beta$ and Tau protein hyperphosphorylation and that they represent a suitable model to study the correlation of phosphorylation of Tau, activation of GSK-3 $\beta$ and the processing of APP by the activity of $\beta$-secretase [39]. iPSCs have been also used to study the neuronal differentiation and the neurodegeneration in a familial form of amyotrophic lateral sclerosis [40] as well as to study the effect of $\alpha$-synuclein gene triplication in Parkinson's disease patients together with the identification of therapeutic compounds against $\alpha$-synuclein accumulation [41]. 


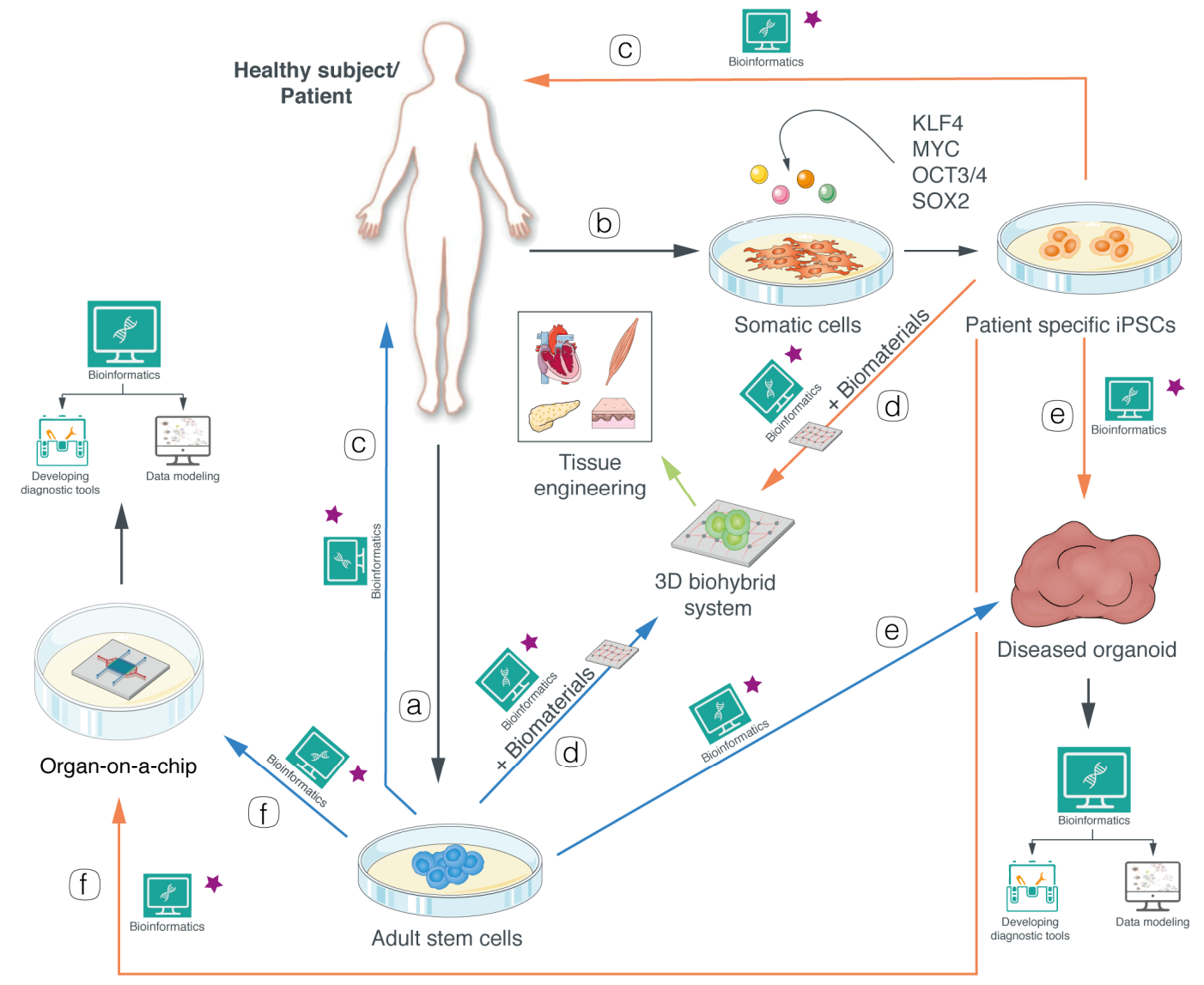

Figure 1. Schematic of ex vivo stem-cell based modeling systems. (a) Autologous stem cells from a donor heathy subject/patient, and patient-specific induced pluripotent stem cells (iPSCs) (b), may be source for generating: (c) Committed/differentiated cells; (d) 3D-biohybrid system; (e) organoids; and (f) organ-on-a-chip. The presence of computer icons indicates the critical role of the computational tools on the model design and the data elaboration. $*$, indicates the application of gene therapy and/or CRISPR/Cas9 to each system.

Nevertheless, when somatic cells are reprogrammed to generate iPSCs, they acquire a series of new intrinsic properties that might generate hurdles in their applications. In fact, in addition to teratoma formation, karyotypic abnormalities and immature phenotype, they are characterized by unpredictable genetic background variations, thus making less reliable the corresponding disease model [42]. In this regard, genome editing tools enable creating isogenic controls iPSCs that differ from the original counterpart only on the gene/s responsible for the disease $[43,44]$. Despite these limitations, iPSCs have shown to be very promising for recapitulating complex genetically disorders especially when combined with gene editing techniques $[33,45,46]$. 
Table 2. List of human iPSCs disease models.

\begin{tabular}{|c|c|c|}
\hline Disease Model & iPSC Source & Ref. \\
\hline Adrenoleukodistrophy & Patient-derived fibroblasts & [47] \\
\hline Alzheimer's disease & Patient-derived fibroblasts & {$[39,48-50]$} \\
\hline Amyotrophic lateral sclerosis & $\begin{array}{c}\text { Patient-derived fibroblasts } \\
\text { Patient-derived peripheral blood } \\
\text { mononuclear cells }\end{array}$ & {$[40,51,52]$} \\
\hline Becker's muscular dystrophy & Patient-derived fibroblasts & [53] \\
\hline Cardiovascular diseases & Patient-derived fibroblasts & [54-56] \\
\hline Cockayne's syndrome & Patient-derived fibroblasts & [57] \\
\hline Down's syndrome & Patient-derived fibroblasts & [53] \\
\hline Duchenne muscular dystrophy & Patient-derived fibroblasts & {$[53,58]$} \\
\hline Familial dysautonomia & Patient-derived fibroblasts & [59] \\
\hline Fragile X-associated tremor/ataxia syndrome & Patient-derived fibroblasts & {$[60,61]$} \\
\hline Gaucher's disease type III & Patient-derived fibroblasts & [53] \\
\hline Huntington's disease & Patient-derived fibroblasts & {$[53,62-64]$} \\
\hline Juvenile diabetes mellitus & Patient-derived fibroblasts & [53] \\
\hline LEOPARD syndrome & Patient-derived fibroblasts & [65] \\
\hline Machado-Joseph disease & Patient-derived fibroblasts & [66] \\
\hline Lesch-Nyhan syndrome & Patient-derived fibroblasts & [53] \\
\hline Parkinson's disease & Patient-derived fibroblasts & {$[41,67]$} \\
\hline Pompe's disease & Patient-derived fibroblasts & [68] \\
\hline Rett syndrome & Patient-derived fibroblasts & [69-71] \\
\hline Prader-Willi syndrome & Patient-derived fibroblasts & {$[72,73]$} \\
\hline Schizophrenia & Patient-derived fibroblasts & {$[74,75]$} \\
\hline Spinal muscular atrophy & Patient-derived fibroblasts & [76] \\
\hline Timothy syndrome & Patient-derived fibroblasts & {$[77,78]$} \\
\hline
\end{tabular}

The selective modification of cells' genetic information was the groundbreaking discovery that revolutionized the concept of cell models. Innovative biotechnologies, together with other previously established, allowed the generation of pathological cells by introducing a defined mutation responsible for the onset of the disease (genome editing) as well as the restoration of a missing gene function in defective cells (gene therapy) (Figure 1). In the case of iPSCs or adult stem cells, they can afterwards be differentiated into diverse cell types involved in the pathology. Accordingly, it is plausible to be able to specifically study each pathological condition in each individual patient and consequently personalize the therapeutic approach (i.e., precision medicine) [79], also with the support of gene therapy approaches and gene editing procedures.

Briefly, gene therapy can be achieved through the use of advanced viral vectors (e.g., lentiviral, adeno-associated, adenoviral, retroviral [80-85]) or non-viral vector systems (e.g., liposomes systems) [86] that drive the therapeutic gene to the host cells [87-91]. The safety and efficacy of these strategies may be evaluated in engineered stem cell models, that are suitable for the treatment validation and for the screening of potential mutational insertions caused by the integration of the target gene in the host DNA [92-95]. Thus, even if the use of animal models is still essential before these treatments reach the clinical phase, stem cells are an alternative models enable to test the effectiveness of treatments in a highly efficient, reproducible and fast manner [84-86,90,91,96]. For instance, in Adenosine Deaminase Activity (ADA-SCID) immunodeficiency therapy (Strimvelis, GlaxoSmithKline (GSK), approved by EMA in 2016 [97]) ADA-genetically engineered hematopoietic stem cells served as basic cell model for validating the effectiveness of the gene delivery procedure and ultimately were used as therapeutic vehicle in vivo [97]. With the same end, in Metachromatic 
Leukodystrophy, hematopoietic stem cells transduced with the ARSA gene were useful for establishing the restoration of the biochemical metabolic defect and were also used as vehicle for the ARSA gene in patients affected [80,81]. Moreover, ongoing studies are showing the relevance of engineered stem cells (e.g., iPSCs, mesenchymal stem cells) for the expression of trophic factors for the treatment of neurodegenerative disorders (Parkinson's disease, Alzheimer's disease, Huntington's disease, and amyotrophic lateral sclerosis [98]). Currently, many pathologies have been targets for gene therapy strategies and are being explored in clinical trials [81,99], or are already available for patients as they have obtained approval from the Food and Drug Administration (FDA) or the European Medicines Agency (EMA).

Genome editing can be achieved through the use of different nucleases that are able to introduce a double-strand break (DSB) in the double helix then resolved via non-homologous end joining (NHEJ) or homologous direct recombination (HDR). These molecular mechanisms are the bases of all the principal genome editing methods that, listed from the first used to the last discovered, are: Zinc finger nucleases (ZFNs, with specificity for 3 base pairs), transcription activator-like effector nucleases (TALENs, one base pair specificity) and the Clustered Regularly Interspaced Short Palindromic Repeat/Cas9 associated system (CRISPR/Cas9, single nucleotide specificity) $[43,100]$. While the first two approaches recognize the target sequence as a result of protein-DNA interactions, CRISPR/Cas9 system utilizes an RNA-DNA base pairing [100]. CRISPR/Cas9 is widely considered to be the most promising tool for manipulating gene expression because, compared to TALENs, it is 3-6 times more cost-effective, it is a much easier technique and in vivo delivery is more effective, although it shows less specificity due to its susceptibility to off-targets [101]. Specifically, CRISPR/Cas9 is engineered to edit DNA in stem cell models by designing specific guide RNA (gRNA) complementary to the target sequence (for extensive description see references [102-106] and Table 3 for computational tools for the design of gRNA). This technique allows manipulation of any cell genome for creating a specific cell phenotype useful to establish accurate ex vivo cell disease models, as well as for correcting DNA mutations linked to pathologies when combined with gene therapy procedures.

Table 3. List of on-line tools for guide RNA (gRNA) design.

\begin{tabular}{crc}
\hline \multicolumn{1}{c}{ Software } & Link & Ref. \\
\hline CasFinder & http://arep.med.harvard.edu/CasFinder/ & {$[107]$} \\
\hline CHOP-CHOP & https://bitbucket.org/valenlab/chopchop/src/master/ & {$[108]$} \\
\hline CRISPR-ERA & http://crispr-era.stanford.edu/ & {$[109]$} \\
\hline CRISPR-DO & https://bitbucket.org/jianma/crisprdo/src/default/ & {$[110]$} \\
\hline GuideScan & https://bitbucket.org/arp2012/guidescan_public/src/master/ & {$[111]$} \\
\hline mm10db & https://github.com/bmds-lab/mm10db/ & {$[112]$} \\
\hline
\end{tabular}

\section{Ex Vivo Stem Cell-Based Systems: Bio-Hybrid Models for Tissue Engineering}

Tissue engineering applies the concepts of engineering and biology to develop scaffold-based systems with the aim of reproducing the structure and the physiological functions of healthy tissues. The use of stem cells and biomaterials allows the generation of ad hoc bio-hybrid systems that represent 3D-models of tissues either for disease modeling (Figure 1) or, after validation, for therapeutic transplantation $[14,37,113,114]$.

These scaffold-based platforms rely on the mechanobiology concept by which biomaterials provide the 3D-structure of native tissues and through their chemical/physical properties are able to specifically steer stem cells toward tissue-specific phenotypes [14]. As a matter of fact, the modulation of physical and chemical properties of biomaterials such as architecture, shape, mechanical properties, and surface structure, have been showed to control the biological responses of stem cells (both stemness and differentiation properties) $[113,115,116]$. Many types of natural or synthetic biomaterials, 
such as polymers, ceramics, bio-glass, composites, or seldom metals [37,117-123], have been combined with different types of stem cells in order to faithfully recapitulate key environmental signals (thus allowing finer cell/tissue models $[11,124])$ and elucidate complex biological phenomena such as stem cell reprogramming pathways and determination processes [14]. To date, some tissue engineering strategies have already reached the market and are used as personalized therapies. (Table 4) [125,126]. For example, many types of skin substitutes, acellular or cellular, are currently available for the treatment of wounds, while both cryopreserved placental membrane and human fibroblasts-derived substitute (HFDs) are approved for the therapy of diabetic foot ulcers [127] (Table 4). Moreover, autologous cartilage cells are used in a phase III clinical trial for the treatment of articular cartilage defects [128] (Table 4).

Table 4. List of tissue engineering therapeutic approaches used in clinic.

\begin{tabular}{|c|c|c|c|c|}
\hline Product & Pathology & Approval & Company & Ref. \\
\hline ChondroCelect & Cartilage diseases & $\begin{array}{l}\text { European Medicines Agency } \\
\text { (EMA) (2009, now withdrawn) }\end{array}$ & TiGenix. & [126] \\
\hline Dermagraft & $\begin{array}{l}\text { Diabetic foot ulcer and venous } \\
\text { leg ulcer }\end{array}$ & USA FDA (2010) & Organogenesis inc. & [127] \\
\hline Epicel & $\begin{array}{l}\text { Deep dermal or full-thickness } \\
\text { burns }\end{array}$ & USA FDA (2016) & Vericel Corporation & {$[129,130]$} \\
\hline Holoclar & Limbal stem cell deficiency & EMA (2015) & $\begin{array}{l}\text { Chiesi Farmaceutici } \\
\text { S.p.A. }\end{array}$ & [131] \\
\hline Maci & Knee cartilage lesions & $\begin{array}{c}\text { USA FDA (2016) } \\
\text { EMA (2013, now withdrawn) }\end{array}$ & Vericel Denmark ApS & {$[132,133]$} \\
\hline Spherox & Cartilage defects in knee joints & EMA (2017) & Codon AG & [134] \\
\hline
\end{tabular}

Among the many scaffold fabrication methods, 3D-bioprinting has recently received a great deal of attention as one of the best tool to obtain specific precise architecture and biochemical composition of biocompatible materials and supporting components [135]. With this technique it could be possible to faithfully recreate native tissue cellular composition, vasculature, and architecture in vitro, thus making biomimetic tissue models, which could then be used for studying disease mechanisms, drug screening, and clinical applications [136,137].

Accordingly, 3D-bioprinting was used for generating in vitro disease models of tumor microenvironments [138], ovarian cancer [139], and drug testing [140]. Even though bioprinting of tissues and organs gave new possibilities to tissue engineering and regenerative medicine [136], their translational application is still facing some challenges. As a matter of fact, current obstacles in 3D-bioprinting methods are the poor scalability, the improvement of bioinks with appropriate biological and mechanical properties suitable to different cell types and the absence of vascularization that cause hurdles in nutrients supply, other than regulatory aspects [141]. Nevertheless, research in 3D-bioprinting technology is advancing and these limitations will be overcome [141].

\section{Ex Vivo Stem Cell-Based Systems: Organoids}

In recent years, progress in 3D-stem cell cultures led to the production of new systems with great potential as cell model platforms (Figure 1). These models have been called organoids, because of their ability to resemble organs, and are characterized by (i) 3D-structure, (ii) different types of cells normally present in the organ that should be modelled, (iii) functional features of the organ, and (iv) self-organization [142]. Self-organization is indeed the most important characteristic of organoids: Under opportune culture conditions (appropriate nutrients and growth factors) primary cells isolated from biopsies, embryonic or adult stem cells, and patient-derived iPSCs can go towards differentiation to develop a 'mini' organ according to intrinsic developmental patterns, thus generating a faithful replica of tissues' morphology and organization [142,143]. Therefore, organoids hold a great promise for ex vivo cell modeling as they are a powerful tool for developmental studies and 
personalized medicine [144]. Accordingly, organoids represent a major improvement in disease modeling compared to animal models, as they overcome ethical issues, are more cost-effective and allow faster analysis [144,145]. Since the development of the first intestinal organoids by Sato and collaborators in 2009 [146], many other models of various tissues have been developed following diverse approaches such as (i) Matrigel scaffold-based, (ii) Embryoid Bodies (EB)-based, and (iii) Air-Liquid Interface (ALI) method [147], and they have been used to model a great range of pathologies, from viral infection to solid cancers, cystic fibrosis, and endometriosis (Table 5). Even if in the last decade efforts have been made for improving organoids fidelity to the in vivo counterpart [148], there are still several critical aspects that have to be taken into account when evaluating organoids predictability. In particular, there is poor control on the shape, size and cells appropriate organization, causing hurdles in terms of scalability and high-throughput approaches. All these variables are mainly arising from a lack of nutrients supply due to the absence of physiological vascularization, which causes the inner part of the organoid to suffer metabolic stress and go towards incorrect differentiation or death $[142,143,149]$. Although these limitations are slowing down organoids' clinical applications, they are still considered one of the best options currently available to build a strong cell model capable of summarizing key features of many diseases.

Table 5. List of human organoids disease models.

\begin{tabular}{|c|c|c|c|}
\hline Organ & Disease & Model Derivation & Ref. \\
\hline Bladder & Bladder cancer & Patients tumor biopsies & {$[150,151]$} \\
\hline Blood vessel & Diabetic vasculopathy & $\begin{array}{c}\text { Commercial iPSCs and } \\
\text { patient-derived endothelial cells }\end{array}$ & [152] \\
\hline \multirow{8}{*}{ Brain } & Microcephaly & $\begin{array}{l}\text { Commercial ESCs and commercial } \\
\text { iPSCs. }\end{array}$ & \multirow{8}{*}{ [153-167] } \\
\hline & Autism spectrum disorder (ASD) & $\begin{array}{l}\text { iPSCs derived from idiopathic ASD } \\
\text { families }\end{array}$ & \\
\hline & $\begin{array}{l}\text { Miller-Dieker syndrome } \\
\text { (lissencephaly) }\end{array}$ & Patient-derived iPSCs & \\
\hline & Glioblastoma & Patients tumor biopsies & \\
\hline & $\begin{array}{l}\text { Neonatal microcephaly due to Zika } \\
\text { virus infection }\end{array}$ & $\begin{array}{l}\text { hiPSCs and human embryonic stem } \\
\text { cells (hESCs) }\end{array}$ & \\
\hline & Schizophrenia & Patient-derived iPSCs & \\
\hline & Familial Alzheimer's disease & Patient-derived iPSCs & \\
\hline & Parkinson's disease & Patient-derived iPSCs & \\
\hline Breast & Breast cancer & Patients tumor biopsies & [168] \\
\hline Colon & Cancer & Patients tumor biopsies & [169] \\
\hline \multirow{3}{*}{ Endometrium } & Endometriosis & Patients tumor biopsies & \multirow{3}{*}[170,171]{} \\
\hline & Endometrial cancer & Patients tumor biopsies & \\
\hline & Lynch syndrome & Patients tumor biopsies & \\
\hline Esophagus & Esophageal Adenocarcinoma & Patients tumor biopsies & {$[172]$} \\
\hline Heart & Local Injury & Commercial hESCs & [173-175] \\
\hline
\end{tabular}


Table 5. Cont.

\begin{tabular}{|c|c|c|c|}
\hline Organ & Disease & Model Derivation & Ref. \\
\hline \multirow{5}{*}{ Intestine } & Cystic fibrosis (CF) & $\begin{array}{l}\text { Intestinal biopsies and crypt } \\
\text { isolation }\end{array}$ & \multirow{5}{*}{ [176-180] } \\
\hline & $\begin{array}{l}\text { Acute gastroenteritis due to human } \\
\text { Noroviruse infection }\end{array}$ & Healthy donors' intestinal biopsies & \\
\hline & $\begin{array}{l}\text { Diarrheal illness due to human } \\
\text { Rotavirus infection }\end{array}$ & $\begin{array}{l}\text { Healthy donors' duodenal and ileal } \\
\text { biopsies }\end{array}$ & \\
\hline & $\begin{array}{l}\text { Diarrheal illness due to } \\
\text { Cryptosporidium infection }\end{array}$ & Healthy donors' duodenal biopsies & \\
\hline & $\begin{array}{l}\text { Respiratory infection due to Middle } \\
\text { East respiratory syndrome } \\
\text { coronavirus }\end{array}$ & Healthy donors' colon biopsies & \\
\hline Kidney & Nephronophthisis & Patients derived iPSCs & [181] \\
\hline \multirow{4}{*}{ LIVER } & $\alpha 1$-antitrypsin deficiency & Liver biopsies & \multirow{4}{*}{ [182-185] } \\
\hline & Primary liver cancers & Patients tumor biopsies & \\
\hline & Hepatitis B infection & Healthy donor iPSCs & \\
\hline & Hepatitis E infection & Liver biopsies of patients affected & \\
\hline \multirow{4}{*}{ LUNG } & Lung cancer & Non-small cell lung cancer biopsies & \multirow{4}{*}{$179,186-188$} \\
\hline & $\begin{array}{l}\text { Diarrheal illness due to } \\
\text { Cryptosporidium infection }\end{array}$ & Non-small cell lung cancer biopsies & \\
\hline & Influenza virus infection & Healthy donor's lung biopsies & \\
\hline & $\begin{array}{l}\text { Lung bronchiolitis and fibrosis due } \\
\text { to respiratory syncytial virus } \\
\text { infection }\end{array}$ & hPSCs & \\
\hline PANCREAS & Pancreatic ductal adenocarcinoma & Patients tumor biopsies & [189-191] \\
\hline PROSTATE & Prostate cancer & Patients metastasis samples & [192] \\
\hline RETINA & Leber congenital amaurosis & Patient-derived iPSCs & [193] \\
\hline \multirow[b]{2}{*}{ STOMACH } & Gastric cancer & Patients tumor biopsies & \multirow[b]{2}{*}{ [194-197] } \\
\hline & $\begin{array}{l}\text { Gastric diseases due to Helicobacter } \\
\text { pylori infection }\end{array}$ & $\begin{array}{l}\text { Gastric/esophageal tumor biopsies } \\
\text { or commercial PSCs }\end{array}$ & \\
\hline
\end{tabular}

\section{Ex Vivo Stem Cell-Based Systems: Organs-on-a-Chip}

A more recent advance in stem cell biology and 3D-tissue engineering is the innovative application of microfluidic techniques for the development of organ-on-a-chip platforms (OOC) (Figure 1). The rationale of the introduction of microfluidic in cell cultures is to reproduce the microenvironment of cells through the use of precise control on fluid flow, biochemical factors and mechanical forces [198]. The aim of OOCs is to reproduce in vitro functional units of organs by reproducing the essential elements that allow physiological functions [199]. This is achieved by the use of micro-fabricated cell culture devices designed to replicate the fundamental architectural characteristics of the organ in exam, which incorporate microchambers and microchannels that allow the growth of diverse cell types in defined culture condition thanks to the capillary controlled fluid flow. Moreover, the tailor-made architectural organization of OOCs enables to study the interactions between different biological compartments, such as cells and the extracellular matrix (ECM), tissue-tissue interfaces and parenchymal-vascular association $[199,200]$. One of the most important aspects of OOCs is that it is possible to combine different biomaterials, microfabrication techniques (extensively reviewed in [201,202]) and cell types for creating multi-compartment and multiphysiological systems that can model tissues pathophysiology. These systems can be developed for reflecting individual pathophysiological conditions by including blood samples, patient-derived primary adult stem cells or iPSCs and by adjusting physiochemical parameters of the flow according to personal health data [203] (Figure 1). This personalized strategy could thus be the new frontier for building a tailored cell disease model able to take into account 
individual pathological variability and, in this way, personalizing treatments [203]. The possibility of harnessing stem cells versatility, differentiated cells specific properties and microfluidic control allowed to build disease models with unprecedented features, as it made possible to reproduce in vitro complex biological structures that could not be obtained with previous cell culturing technologies such as the blood-brain barrier [204] (Table 6). As a matter of fact, in the past five years many disease models have been developed, such as lung-on-a-chip for cancer [205] or coupled-OOCs of liver and pancreas spheroids able to maintain glucose homeostasis for modeling type 2 diabetes [206] (Table 6). Of note, different OOC models can be linked to build an ideal 'human-on-a-chip' which could theoretically serve as the ultimate alternative to animal models for its capacity to predict multiorgan biological interactions and response to therapeutic treatments [202,207].

In spite of the many advantages that OOCs have, they rely on the ability of the scientist to artificially reconstruct the correct microenvironment using the correct cell types and arranging them as they would be in the physiological state. Therefore, future perspective of 3D cell modeling will involve the synergic combination of OOCs and organoids, for the possibility of precisely control microenvironmental conditions and exploit organoids self-organization, with the aim of obtaining the best ex vivo cell modeling technology [208].

Table 6. List of human organ-on-a-chip disease models.

\begin{tabular}{|c|c|c|c|}
\hline Organ & Disease & Model Derivation & Ref. \\
\hline \multirow{4}{*}{ BRAIN } & Alzheimer's disease & $\begin{array}{l}\text { Commercial neural progenitor cells and } \\
\text { commercial microglia cell line }\end{array}$ & \multirow{4}{*}{ [204,209-212] } \\
\hline & Blood-brain barrier dysfunctions & $\begin{array}{l}\text { Commercial cell lines (endothelial cells, } \\
\text { brain pericytes, astrocytes) and healthy } \\
\text { donors-derived iPSCs }\end{array}$ & \\
\hline & Neuroinflammation & $\begin{array}{l}\text { Commercial cell lines (endothelial cells, } \\
\text { brain pericytes, astrocytes) }\end{array}$ & \\
\hline & Brain cancer & Commercial glioblastoma cells & \\
\hline \multirow{2}{*}{ HEART } & $\begin{array}{l}\text { Mitochondrial cardiomyopathy of } \\
\text { Barth syndrome }\end{array}$ & Patients-derived iPSCs & \multirow{2}{*}{ [213-215] } \\
\hline & Chronic drug exposure & Commercial human embryonic stem cells & \\
\hline KIDNEY & Antibiotic nephrotoxicity & Healthy donors human kidney tissues & [216] \\
\hline \multirow{4}{*}{ LIVER } & Hepatitis B infection & $\begin{array}{c}\text { Commercial HepDE19 cells, Primary } \\
\text { human hepatocytes, Kupffer Cells, } \\
\text { HepG2 cells }\end{array}$ & \multirow{4}{*}{ [217-221] } \\
\hline & Drug hepatotoxicity & $\begin{array}{l}\text { Commercial HepG2 cells, human umbilical } \\
\text { vein cells (EAhy926), human stellate cells } \\
\text { (LX-2), human histiocytic lymphoma (U937) } \\
\text { and basement membrane extract }\end{array}$ & \\
\hline & Drug hepatotoxicity & $\begin{array}{l}\text { Commercial primary human hepatocytes, } \\
\text { monoblast derived Kupfer cells, stellate } \\
\text { cells (LX-2), human dermal microvascular } \\
\text { endothelial cells and isolated primary } \\
\text { human polymorphonuclear leukocytes } \\
\text { from healthy donors }\end{array}$ & \\
\hline & Non-alcoholic fatty liver disease & Commercial HepG2 cells & \\
\hline \multirow{3}{*}{ LUNG } & Protein-induced lung inflammation & $\begin{array}{l}\text { Commercial bronchial epithelial cell line } \\
\text { and healthy donors fibrocytes }\end{array}$ & \multirow{3}{*}[205,222,223]{} \\
\hline & Idiopathic pulmonary fibrosis & Commercial alveolar epithelial-like cells & \\
\hline & Lung cancer & $\begin{array}{c}\text { Commercial non-small cell lung cancer cells } \\
\text { and commercial human fetal lung } \\
\text { fibroblasts }\end{array}$ & \\
\hline
\end{tabular}




\section{Conclusions}

In this review, we have documented the significant improvements in disease modeling using human adult stem cells and iPSCs, highlighting how their contribution in generating more elaborated 3D-models (organoids, organ-on-a-chip, and bio-hybrid systems) have greatly facilitated our understanding and ability to treat human disease. Noteworthy, we have also pointed out that the tremendous advancement of the field has highlighted the need for these models to be accurate, efficient and safe, in order to accomplish valid differentiation protocols and development of effective therapies. In this regard, computational tools able to predict complex biological systems, together with genome editing and gene therapy technologies support researchers in the development of more proficient disease models. Collectively, the issues discussed emphasized ex vivo-stem cell models as an alternative or complementary system to animal disease models.

Author Contributions: Conceptualization, C.A., I.T., M.B., F.M., and S.M.; Software, F.M.; Writing-Review and Editing, C.A., I.T., M.B., F.M., and S.M.; Supervision, S.M.; Funding Acquisition, S.M. All authors have read and agreed to the published version of the manuscript.

Funding: This research was funded by grant Fondo Ricerca di Base 2017, DCBB, University of Perugia, Italy and grant by FFABRMARTINO-2018 from MIUR, Italy, awarded to S.M.

Acknowledgments: We thank all researchers cited in this review and we apologize to colleagues in the field for not being able to cite many important papers due to the limitation of the article.

Conflicts of Interest: The authors declare no conflict of interest.

\section{References}

1. McGonigle, P.; Ruggeri, B. Animal models of human disease: Challenges in enabling translation. Biochem. Pharmacol. 2014, 87, 162-171. [CrossRef]

2. Hartung, T. Thoughts on limitations of animal models. Park. Relat. Disord. 2008, 14, S81-S83. [CrossRef]

3. Mak, I.W.Y.; Evaniew, N.; Ghert, M. Lost in translation: Animal models and clinical trials in cancer treatment. Am. J. Transl. Res. 2014, 6, 114-118. [PubMed]

4. Lawson, C.A.; Martin, D.R. Animal models of GM2 gangliosidosis: Utility and limitations. Appl. Clin. Genet. 2016, 9, 111-120. [CrossRef] [PubMed]

5. Tannenbaum, J.; Bennett, B.T. Russell and Burch's 3Rs then and now: The need for clarity in definition and purpose. J. Am. Assoc. Lab. Anim. Sci. 2015, 54, 120-132. [PubMed]

6. Swain, P. Basic Techniques and Limitations in Establishing Cell Culture: A Mini Review. Adv. Anim. Vet. Sci. 2014, 2, 1-10. [CrossRef]

7. Kapałczyńska, M.; Kolenda, T.; Przybyła, W.; Zajączkowska, M.; Teresiak, A.; Filas, V.; Ibbs, M.; Bliźniak, R.; Łuczewski, Ł.; Lamperska, K. 2D and 3D cell cultures-A comparison of different types of cancer cell cultures. Arch. Med. Sci. 2018, 14, 910-919. [CrossRef]

8. Morena, F.; Argentati, C.; Bazzucchi, M.; Emiliani, C.; Martino, S. Above the Epitranscriptome: RNA Modifications and Stem Cell Identity. Genes 2018, 9, 329. [CrossRef]

9. Morena, F.; Argentati, C.; Trotta, R.; Crispoltoni, L.; Stabile, A.; Pistilli, A.; di Baldassarre, A.; Calafiore, R.; Montanucci, P.; Basta, G.; et al. A comparison of lysosomal enzymes expression levels in peripheral blood of mild- and severe-Alzheimer's disease and MCI patients: Implications for regenerative medicine approaches. Int. J. Mol. Sci. 2017, 18, 1806. [CrossRef]

10. Saji Joseph, J.; Tebogo Malindisa, S.; Ntwasa, M. Two-Dimensional (2D) and Three-Dimensional (3D) Cell Culturing in Drug Discovery. In Cell Culture; IntechOpen: Rijeka, Croatia, 2019.

11. Huh, D.; Hamilton, G.A.; Ingber, D.E. From 3D cell culture to organs-on-chips. Trends Cell Biol. 2011, 21, 745-754. [CrossRef]

12. Fang, Y.; Eglen, R.M. Three-Dimensional Cell Cultures in Drug Discovery and Development. SLAS Discov. 2017, 22, 456-472. [PubMed]

13. Ravi, M.; Paramesh, V.; Kaviya, S.R.; Anuradha, E.; Paul Solomon, F.D. 3D cell culture systems: Advantages and applications. J. Cell. Physiol. 2015, 230, 16-26. [CrossRef] [PubMed] 
14. Argentati, C.; Morena, F.; Tortorella, I.; Bazzucchi, M.; Porcellati, S.; Emiliani, C.; Martino, S. Insight into Mechanobiology: How Stem Cells Feel Mechanical Forces and Orchestrate Biological Functions. Int. J. Mol. Sci. 2019, 20, 5337. [CrossRef]

15. Cukierman, E.; Pankov, R.; Yamada, K.M. Cell interactions with three-dimensional matrices. Curr. Opin. Cell Biol. 2002, 14, 633-640. [CrossRef]

16. Luca, A.C.; Mersch, S.; Deenen, R.; Schmidt, S.; Messner, I.; Schäfer, K.L.; Baldus, S.E.; Huckenbeck, W.; Piekorz, R.P.; Knoefel, W.T.; et al. Impact of the 3D Microenvironment on Phenotype, Gene Expression, and EGFR Inhibition of Colorectal Cancer Cell Lines. PLoS ONE 2013, 8, e59689. [CrossRef]

17. Myungjin Lee, J.; Mhawech-Fauceglia, P.; Lee, N.; Cristina Parsanian, L.; Gail Lin, Y.; Andrew Gayther, S.; Lawrenson, K. A three-dimensional microenvironment alters protein expression and chemosensitivity of epithelial ovarian cancer cells in vitro. Lab. Investig. 2013, 93, 528-542. [CrossRef]

18. Edmondson, R.; Broglie, J.J.; Adcock, A.F.; Yang, L. Three-Dimensional cell culture systems and their applications in drug discovery and cell-based biosensors. Assay Drug Dev. Technol. 2014, 12, $207-218$. [CrossRef]

19. Knight, E.; Przyborski, S. Advances in 3D cell culture technologies enabling tissue-like structures to be created in vitro. J. Anat. 2015, 227, 746-756. [CrossRef]

20. Machado, D.; Costa, R.S.; Rocha, M.; Ferreira, E.C.; TidRocha, I. Modeling formalisms in systems biology. AMB Express 2011, 1, 1-14. [CrossRef]

21. Papatsenko, D.; Lemischka, I.R. Emerging Modeling Concepts and Solutions in Stem Cell Research. In Current Topics in Developmental Biology; Academic Press Inc.: New York, NY, USA, 2016; pp. $709-721$. ISBN 9780128029565.

22. Calzone, L.; Fages, F; Soliman, S. BIOCHAM: An environment for modeling biological systems and formalizing experimental knowledge. Bioinformatics 2006, 22, 805-1807. [CrossRef]

23. Kumar, S.P.; Feidler, J.C. BioSPICE: A Computational Infrastructure for Integrative Biology. Omi. A J. Integr. Biol. 2003, 7, 225. [CrossRef] [PubMed]

24. Cuellar, A.; Hedley, W.; Nelson, M.; Lloyd, C.; Halstead, M.; Bullivant, D.; Nickerson, D.; Hunter, P.; Nielsen, P. The CellML 1.1 Specification. J. Integr. Bioinform. 2015, 12, 259. [CrossRef] [PubMed]

25. Bergmann, F.T.; Hoops, S.; Klahn, B.; Kummer, U.; Mendes, P.; Pahle, J.; Sahle, S. COPASI and its applications in biotechnology. J. Biotechnol. 2017, 261, 215-220. [CrossRef] [PubMed]

26. Arjunan, S.N. A Guide to Modeling Reaction-Diffusion of Molecules with the E-Cell System; Springer: New York, NY, USA, 2013.

27. Sütterlin, T.; Kolb, C.; Dickhaus, H.; Jäger, D.; Grabe, N. Bridging the scales: Semantic integration of quantitative SBML in graphical multi-cellular models and simulations with EPISIM and COPASI. Bioinformatics 2013, 29, 223-229. [CrossRef] [PubMed]

28. Tapia, J.J.; Saglam, A.S.; Czech, J.; Kuczewski, R.; Bartol, T.M.; Sejnowski, T.J.; Faeder, J.R. MCell-R: A Particle-Resolution Network-Free Spatial Modeling Framework. In Methods in Molecular Biology; Humana Press Inc.: Totowa, NJ, USA, 2019; pp. 203-229.

29. Kerr, R.A.; Bartol, T.M.; Kaminsky, B.; Dittrich, M.; Chang, J.C.J.; Baden, S.B.; Sejnowski, T.J.; Stiles, J.R. Fast Monte Carlo simulation methods for biological reaction-diffusion systems in solution and on surfaces. SIAM J. Sci. Comput. 2008, 30, 3126-3149. [CrossRef] [PubMed]

30. Starruß, J.; De Back, W.; Brusch, L.; Deutsch, A. Morpheus: A user-friendly modeling environment for multiscale and multicellular systems biology. Bioinformatics 2014, 30, 1331-1332. [CrossRef]

31. Merks, R.M.H.; Glazier, J.A. A cell-centered approach to developmental biology. Phys. A Stat. Mech. Appl. 2005, 352, 113-130. [CrossRef]

32. Resasco, D.C.; Gao, F.; Morgan, F.; Novak, I.L.; Schaff, J.C.; Slepchenko, B.M. Virtual Cell: Computational tools for modeling in cell biology. Wiley Interdiscip. Rev. Syst. Biol. Med. 2012, 4, 129-140. [CrossRef]

33. Sterneckert, J.L.; Reinhardt, P.; Schöler, H.R. Investigating human disease using stem cell models. Nat. Rev. Genet. 2014, 15, 625-639. [CrossRef]

34. Evans, M.J.; Kaufman, M.H. Establishment in culture of pluripotential cells from mouse embryos. Nature 1981, 292, 154-156. [CrossRef]

35. Johnson, J.Z.; Hockemeyer, D. Human stem cell-based disease modeling: Prospects and challenges. Curr. Opin. Cell Biol. 2015, 37, 84-90. [CrossRef] [PubMed] 
36. Martino, S.; Di Girolamo, I.; Cavazzin, C.; Tiribuzi, R.; Galli, R.; Rivaroli, A.; Valsecchi, M.; Sandhoff, K.; Sonnino, S.; Vescovi, A.; et al. Neural precursor cell cultures from GM2 gangliosidosis animal models recapitulate the biochemical and molecular hallmarks of the brain pathology. J. Neurochem. 2009, 109, 135-147. [CrossRef] [PubMed]

37. Argentati, C.; Morena, F.; Bazzucchi, M.; Armentano, I.; Emiliani, C.; Martino, S. Adipose stem cell translational applications: From bench-to-bedside. Int. J. Mol. Sci. 2018, 19, 3475. [CrossRef] [PubMed]

38. Takahashi, K.; Tanabe, K.; Ohnuki, M.; Narita, M.; Ichisaka, T.; Tomoda, K.; Yamanaka, S. Induction of Pluripotent Stem Cells from Adult Human Fibroblasts by Defined Factors. Cell 2007, 131, 861-872. [CrossRef] [PubMed]

39. Israel, M.A.; Yuan, S.H.; Bardy, C.; Reyna, S.M.; Mu, Y.; Herrera, C.; Hefferan, M.P.; Van Gorp, S.; Nazor, K.L.; Boscolo, F.S.; et al. Probing sporadic and familial Alzheimer's disease using induced pluripotent stem cells. Nature 2012, 482, 216-220. [CrossRef] [PubMed]

40. Dimos, J.T.; Rodolfa, K.T.; Niakan, K.K.; Weisenthal, L.M.; Mitsumoto, H.; Chung, W.; Croft, G.F.; Saphier, G.; Leibel, R.; Goland, R.; et al. Induced pluripotent stem cells generated from patients with ALS can be differentiated into motor neurons. Science 2008, 321, 1218-1221. [CrossRef] [PubMed]

41. Devine, M.J.; Ryten, M.; Vodicka, P.; Thomson, A.J.; Burdon, T.; Houlden, H.; Cavaleri, F.; Nagano, M.; Drummond, N.J.; Taanman, J.W.; et al. Parkinson's disease induced pluripotent stem cells with triplication of the $\alpha$-synuclein locus. Nat. Commun. 2011, 2, 1-10. [CrossRef]

42. Duelen, R.; Corvelyn, M.; Tortorella, I.; Leonardi, L.; Chai, Y.C.; Sampaolesi, M. Medicinal Biotechnology for Disease Modeling, Clinical Therapy, and Drug Discovery and Development. In Introduction to Biotech Entrepreneurship: From Idea to Business; Springer International Publishing: Cham, Switzerland, 2019; pp. 89-128.

43. Cai, M.; Yang, Y. Targeted Genome Editing Tools for Disease Modeling and Gene Therapy. Curr. Gene Ther. 2014, 14, 2-9. [CrossRef]

44. Zomer, H.D.; Vidane, A.S.; Gonçalves, N.N.; Ambrósio, C.E. Mesenchymal and induced pluripotent stem cells: General insights and clinical perspectives. Stem Cells Cloning Adv. Appl. 2015, 8, 125-134. [CrossRef]

45. Frati, G.; Luciani, M.; Meneghini, V.; De Cicco, S.; Ståhlman, M.; Blomqvist, M.; Grossi, S.; Filocamo, M.; Morena, F.; Menegon, A.; et al. Human iPSC-based models highlight defective glial and neuronal differentiation from neural progenitor cells in metachromatic leukodystrophy. Cell Death Dis. 2018, 9, 1-15. [CrossRef]

46. Meneghini, V.; Frati, G.; Sala, D.; De Cicco, S.; Luciani, M.; Cavazzin, C.; Paulis, M.; Mentzen, W.; Morena, F.; Giannelli, S.; et al. Generation of Human Induced Pluripotent Stem Cell-Derived Bona Fide Neural Stem Cells for Ex Vivo Gene Therapy of Metachromatic Leukodystrophy. Stem Cells Transl. Med. 2017, 6, 352-368. [CrossRef] [PubMed]

47. Jang, J.; Kang, H.C.; Kim, H.S.; Kim, J.Y.; Huh, Y.J.; Kim, D.S.; Yoo, J.E.; Lee, J.A.; Lim, B.; Lee, J.; et al. Induced pluripotent stem cell models from X-linked adrenoleukodystrophy patients. Ann. Neurol. 2011, 70, 402-409. [CrossRef] [PubMed]

48. Kondo, T.; Asai, M.; Tsukita, K.; Kutoku, Y.; Ohsawa, Y.; Sunada, Y.; Imamura, K.; Egawa, N.; Yahata, N.; Okita, K.; et al. Modeling Alzheimer's disease with iPSCs reveals stress phenotypes associated with intracellular $A \beta$ and differential drug responsiveness. Cell Stem Cell 2013, 12, 487-496. [CrossRef] [PubMed]

49. Essayan-Perez, S.; Zhou, B.; Nabet, A.M.; Wernig, M.; Huang, Y.W.A. Modeling Alzheimer's disease with human iPS cells: Advancements, lessons, and applications. Neurobiol. Dis. 2019, 130, 104503. [CrossRef] [PubMed]

50. Mungenast, A.E.; Siegert, S.; Tsai, L.H. Modeling Alzheimer's disease with human induced pluripotent stem (iPS) cells. Mol. Cell. Neurosci. 2016, 73, 13-31. [CrossRef] [PubMed]

51. Egawa, N.; Kitaoka, S.; Tsukita, K.; Naitoh, M.; Takahashi, K.; Yamamoto, T.; Adachi, F.; Kondo, T.; Okita, K.; Asaka, I.; et al. Drug screening for ALS using patient-specific induced pluripotent stem cells. Sci. Transl. Med. 2012, 4, 145ra104. [CrossRef] [PubMed]

52. Bossolasco, P.; Sassone, F.; Gumina, V.; Peverelli, S.; Garzo, M.; Silani, V. Motor neuron differentiation of iPSCs obtained from peripheral blood of a mutant TARDBP ALS patient. Stem Cell Res. 2018, 30, 61-68. [CrossRef] 
53. Park, I.H.; Arora, N.; Huo, H.; Maherali, N.; Ahfeldt, T.; Shimamura, A.; Lensch, M.W.; Cowan, C.; Hochedlinger, K.; Daley, G.Q. Disease-Specific Induced Pluripotent Stem Cells. Cell 2008, 134, 877-886. [CrossRef]

54. Moretti, A.; Bellin, M.; Welling, A.; Jung, C.B.; Lam, J.T.; Bott-Flügel, L.; Dorn, T.; Goedel, A.; Höhnke, C.; Hofmann, F.; et al. Patient-specific induced pluripotent stem-cell models for long-QT syndrome. N. Engl. J. Med. 2010, 363, 1397-1409. [CrossRef]

55. Matsa, E.; Rajamohan, D.; Dick, E.; Young, L.; Mellor, I.; Staniforth, A.; Denning, C. Drug evaluation in cardiomyocytes derived from human induced pluripotent stem cells carrying a long QT syndrome type 2 mutation. Eur. Heart J. 2011, 32, 952-962. [CrossRef]

56. Ma, D.; Wei, H.; Lu, J.; Ho, S.; Zhang, G.; Sun, X.; Oh, Y.; Tan, S.H.; Ng, M.L.; Shim, W.; et al. Generation of patient-specific induced pluripotent stem cell-derived cardiomyocytes as a cellular model of arrhythmogenic right ventricular cardiomyopathy. Eur. Heart J. 2013, 34, 1122-1133. [CrossRef] [PubMed]

57. de Sousa Andrade, L.N.; Nathanson, J.L.; Yeo, G.W.; Menck, C.F.M.; Muotri, A.R. Evidence for premature aging due to oxidative stress in iPSCs from Cockayne syndrome. Hum. Mol. Genet. 2012, 21, 3825-3834. [CrossRef] [PubMed]

58. Kazuki, Y.; Hiratsuka, M.; Takiguchi, M.; Osaki, M.; Kajitani, N.; Hoshiya, H.; Hiramatsu, K.; Yoshino, T.; Kazuki, K.; Ishihara, C.; et al. Complete genetic correction of iPS cells from duchenne muscular dystrophy. Mol. Ther. 2010, 18, 386-393. [CrossRef] [PubMed]

59. Lee, G.; Papapetrou, E.P.; Kim, H.; Chambers, S.M.; Tomishima, M.J.; Fasano, C.A.; Ganat, Y.M.; Menon, J.; Shimizu, F.; Viale, A.; et al. Modelling pathogenesis and treatment of familial dysautonomia using patient-specific iPSCs. Nature 2009, 461, 402-406. [CrossRef] [PubMed]

60. Urbach, A.; Bar-Nur, O.; Daley, G.Q.; Benvenisty, N. Differential modeling of fragile X syndrome by human embryonic stem cells and induced pluripotent stem cells. Cell Stem Cell 2010, 6, 407-411. [CrossRef]

61. Liu, J.; Kościelska, K.A.; Cao, Z.; Hulsizer, S.; Grace, N.; Mitchell, G.; Nacey, C.; Githinji, J.; McGee, J.; Garcia-Arocena, D.; et al. Signaling defects in iPSC-derived fragile X premutation neurons. Hum. Mol. Genet. 2012, 21, 3795-3805. [CrossRef]

62. Camnasio, S.; Carri, A.D.; Lombardo, A.; Grad, I.; Mariotti, C.; Castucci, A.; Rozell, B.; Riso, P.L.; Castiglioni, V.; Zuccato, C.; et al. The first reported generation of several induced pluripotent stem cell lines from homozygous and heterozygous Huntington's disease patients demonstrates mutation related enhanced lysosomal activity. Neurobiol. Dis. 2012, 46, 41-51. [CrossRef]

63. Jeon, I.; Lee, N.; Li, J.Y.; Park, I.H.; Park, K.S.; Moon, J.; Shim, S.H.; Choi, C.; Chang, D.J.; Kwon, J.; et al. Neuronal properties, in vivo effects, and pathology of a Huntington's disease patient-derived induced pluripotent stem cells. Stem Cells 2012, 30, 2054-2062. [CrossRef]

64. Zhang, N.; An, M.C.; Montoro, D.; Ellerby, L.M. Characterization of human Huntington's disease cell model from induced pluripotent stem cells. PLoS Curr. 2010, 2010, 1-11. [CrossRef]

65. Carvajal-Vergara, X.; Sevilla, A.; Dsouza, S.L.; Ang, Y.S.; Schaniel, C.; Lee, D.F.; Yang, L.; Kaplan, A.D.; Adler, E.D.; Rozov, R.; et al. Patient-specific induced pluripotent stem-cell-derived models of LEOPARD syndrome. Nature 2010, 465, 808-812. [CrossRef]

66. Koch, P.; Breuer, P.; Peitz, M.; Jungverdorben, J.; Kesavan, J.; Poppe, D.; Doerr, J.; Ladewig, J.; Mertens, J.; Tüting, T.; et al. Excitation-induced ataxin-3 aggregation in neurons from patients with Machado-Joseph disease. Nature 2011, 480, 543-546. [CrossRef] [PubMed]

67. Cooper, O.; Seo, H.; Andrabi, S.; Guardia-laguarta, C.; Sundberg, M.; Mclean, J.R.; Carrillo-reid, L.; Xie, Z.; Hargus, G.; Deleidi, M.; et al. Familial Parkinson's disease iPSCs show cellular deficits in mitochondrial responses that can be pharmacologically rescued. Sci. Transl. Med. 2012, 4, ra90-ra141. [CrossRef] [PubMed]

68. Huang, H.P.; Chen, P.H.; Hwu, W.L.; Chuang, C.Y.; Chien, Y.H.; Stone, L.; Chien, C.L.; Li, L.T.; Chiang, S.C.; Chen, H.F.; et al. Human Pompe disease-induced pluripotent stem cells for pathogenesis modeling, drug testing and disease marker identification. Hum. Mol. Genet. 2011, 20, 4851-4864. [CrossRef] [PubMed]

69. Marchetto, M.C.N.; Carromeu, C.; Acab, A.; Yu, D.; Yeo, G.W.; Mu, Y.; Chen, G.; Gage, F.H.; Muotri, A.R. A model for neural development and treatment of rett syndrome using human induced pluripotent stem cells. Cell 2010, 143, 527-539. [CrossRef] [PubMed]

70. Ananiev, G.; Williams, E.C.; Li, H.; Chang, Q. Isogenic pairs of wild type and mutant induced pluripotent stem cell (iPSC) lines from rett syndrome patients as In Vitro disease model. PLoS ONE 2011, 6, e25255. [CrossRef] 
71. Cheung, A.Y.L.; Horvath, L.M.; Grafodatskaya, D.; Pasceri, P.; Weksberg, R.; Hotta, A.; Carrel, L.; Ellis, J. Isolation of MECP2-null Rett Syndrome patient hiPS cells and isogenic controls through X-chromosome inactivation. Hum. Mol. Genet. 2011, 20, 2103-2115. [CrossRef]

72. Chamberlain, S.J.; Chen, P.F.; Ng, K.Y.; Bourgois-Rocha, F.; Lemtiri-Chlieh, F.; Levine, E.S.; Lalande, M. Induced pluripotent stem cell models of the genomic imprinting disorders Angelman and Prader-Willi syndromes. Proc. Natl. Acad. Sci. USA 2010, 107, 17668-17673. [CrossRef]

73. Yang, J.; Cai, J.; Zhang, Y.; Wang, X.; Li, W.; Xu, J.; Li, F.; Guo, X.; Deng, K.; Zhong, M.; et al. Induced pluripotent stem cells can be used to model the genomic imprinting disorder Prader-Willi syndrome. J. Biol. Chem. 2010, 285, 40303-40311. [CrossRef]

74. Brennand, K.J.; Simone, A.; Jou, J.; Gelboin-Burkhart, C.; Tran, N.; Sangar, S.; Li, Y.; Mu, Y.; Chen, G.; Yu, D.; et al. Modelling schizophrenia using human induced pluripotent stem cells. Nature 2011, 473, 221-225. [CrossRef]

75. da Silveira Paulsen, B.; de Moraes Maciel, R.; Galina, A.; da Silveira, M.S.; dos Santos Souza, C.; Drummond,H.; Pozzatto, E.N.; Junior, H.S.; Chicaybam, L.; Massuda, R.; et al. Altered oxygen metabolism associated to neurogenesis of induced pluripotent stem cells derived from a schizophrenic patient. Cell Transplant. 2012, 21, 1547-1559.

76. Ebert, A.D.; Yu, J.; Rose, F.F.; Mattis, V.B.; Lorson, C.L.; Thomson, J.A.; Svendsen, C.N. Induced pluripotent stem cells from a spinal muscular atrophy patient. Nature 2009, 457, 277-280. [CrossRef] [PubMed]

77. Yazawa, M.; Hsueh, B.; Jia, X.; Pasca, A.M.; Bernstein, J.A.; Hallmayer, J.; Dolmetsch, R.E. Using induced pluripotent stem cells to investigate cardiac phenotypes in Timothy syndrome. Nature 2011, 471, 230-236. [CrossRef] [PubMed]

78. Paşca, S.P.; Portmann, T.; Voineagu, I.; Yazawa, M.; Shcheglovitov, A.; Paşca, A.M.; Cord, B.; Palmer, T.D.; Chikahisa, S.; Nishino, S.; et al. Using iPSC-derived neurons to uncover cellular phenotypes associated with Timothy syndrome. Nat. Med. 2011, 17, 1657-1662. [CrossRef] [PubMed]

79. Arjmand, B.; Goodarzi, P.; Mohamadi-Jahani, F.; Falahzadeh, K.; Larijani, B. Personalized regenerative medicine. Acta Med. Iran. 2017, 55, 144-149.

80. Biffi, A.; Montini, E.; Lorioli, L.; Cesani, M.; Fumagalli, F.; Plati, T.; Baldoli, C.; Martino, S.; Calabria, A.; Canale, S.; et al. Lentiviral hematopoietic stem cell gene therapy benefits metachromatic leukodystrophy. Science 2013, 341, 1233158. [CrossRef]

81. Sessa, M.; Lorioli, L.; Fumagalli, F.; Acquati, S.; Redaelli, D.; Baldoli, C.; Canale, S.; Lopez, I.D.; Morena, F.; Calabria, A.; et al. Lentiviral haemopoietic stem-cell gene therapy in early-onset metachromatic leukodystrophy: An ad-hoc analysis of a non-randomised, open-label, phase 1/2 trial. Lancet (Lond. Engl.) 2016, 388, 476-487. [CrossRef]

82. Consiglio, A.; Quattrini, A.; Martino, S.; Bensadoun, J.C.; Dolcetta, D.; Trojani, A.; Benaglia, G.; Marchesini, S.; Cestari, V.; Oliverio, A.; et al. In vivo gene therapy of metachromatic leukodystrophy by lentiviral vectors: Correction of neuropathology and protection against learning impairments in affected mice. Nat. Med. 2001, 7, 310-316. [CrossRef]

83. Martino, S.; Marconi, P.; Tancini, B.; Dolcetta, D.; De Angelis, M.G.C.; Montanucci, P.; Bregola, G.; Sandhoff, K.; Bordignon, C.; Emiliani, C.; et al. A direct gene transfer strategy via brain internal capsule reverses the biochemical defect in Tay-Sachs disease. Hum. Mol. Genet. 2005, 14, 2113-2123. [CrossRef]

84. Neri, M.; Ricca, A.; Di Girolamo, I.; Alcala'-Franco, B.; Cavazzin, C.; Orlacchio, A.; Martino, S.; Naldini, L.; Gritti, A. Neural stem cell gene therapy ameliorates pathology and function in a mouse model of globoid cell leukodystrophy. Stem Cells 2011, 29, 1559-1571. [CrossRef]

85. Spronck, E.A.; Brouwers, C.C.; Vallès, A.; de Haan, M.; Petry, H.; van Deventer, S.J.; Konstantinova, P.; Evers, M.M. AAV5-miHTT Gene Therapy Demonstrates Sustained Huntingtin Lowering and Functional Improvement in Huntington Disease Mouse Models. Mol. Ther. Methods Clin. Dev. 2019, 13, 334-343. [CrossRef]

86. Nayerossadat, N.; Ali, P.; Maedeh, T. Viral and nonviral delivery systems for gene delivery. Adv. Biomed. Res. 2012, 1, 27. [CrossRef]

87. Kumar, S.R.; Markusic, D.M.; Biswas, M.; High, K.A.; Herzog, R.W. Clinical development of gene therapy: Results and lessons from recent successes. Mol. Ther. Methods Clin. Dev. 2016, 3, 16034. [CrossRef] [PubMed]

88. Dunbar, C.E.; High, K.A.; Joung, J.K.; Kohn, D.B.; Ozawa, K.; Sadelain, M. Gene therapy comes of age. Science 2018, 359, eaan4672. [CrossRef] [PubMed] 
89. Shahryari, A.; Jazi, M.S.; Mohammadi, S.; Nikoo, H.R.; Nazari, Z.; Hosseini, E.S.; Burtscher, I.; Mowla, S.J.; Lickert, H. Development and clinical translation of approved gene therapy products for genetic disorders. Front. Genet. 2019, 10, 868. [CrossRef] [PubMed]

90. Gopinath, C.; Nathar, T.; Ghosh, A.; Hickstein, D.; Remington Nelson, E. Contemporary Animal Models For Human Gene Therapy Applications. Curr. Gene Ther. 2015, 15, 531-540. [CrossRef]

91. Elverum, K.; Whitman, M. Delivering cellular and gene therapies to patients: Solutions for realizing the potential of the next generation of medicine. Gene Ther. 2019, 2019, 1-8. [CrossRef]

92. Ornaghi, F.; Sala, D.; Tedeschi, F.; Maffia, M.C.; Bazzucchi, M.; Morena, F.; Valsecchi, M.; Aureli, M.; Martino, S.; Gritti, A. Novel bicistronic lentiviral vectors correct $\beta$-Hexosaminidase deficiency in neural and hematopoietic stem cells and progeny: Implications for in vivo end ex vivo gene therapy of GM2 gangliosidosis. Neurobiol. Dis. 2019, 2019, 104667. [CrossRef]

93. Ungari, S.; Montepeloso, A.; Morena, F.; Cocchiarella, F.; Recchia, A.; Martino, S.; Gentner, B.; Naldini, L.; Biffi, A. Design of a regulated lentiviral vector for hematopoietic stem cell gene therapy of globoid cell leukodystrophy. Mol. Ther. Methods Clin. Dev. 2015, 2, 15038. [CrossRef]

94. Martino, S.; Cavalieri, C.; Emiliani, C.; Dolcetta, D.; Cusella De Angelis, M.G.; Chigorno, V.; Severini, G.M.; Sandhoff, K.; Bordignon, C.; Sonnino, S.; et al. Restoration of the GM2 ganglioside metabolism in bone marrow-derived stromal cells from Tay-Sachs disease animal model. Neurochem. Res. 2002, 27, 793-800. [CrossRef]

95. Martino, S.; Emiliani, C.; Tancini, B.; Severini, G.M.; Chigorno, V.; Bordignon, C.; Sonnino, S.; Orlacchio, A. Absence of Metabolic Cross-correction in Tay-Sachs Cells. J. Biol. Chem. 2002, 277, 20177-20184. [CrossRef]

96. Meneghini, V.; Lattanzi, A.; Tiradani, L.; Bravo, G.; Morena, F.; Sanvito, F.; Calabria, A.; Bringas, J.; Fisher-Perkins, J.M.; Dufour, J.P.; et al. Pervasive supply of therapeutic lysosomal enzymes in the CNS of normal and Krabbe-affected non-human primates by intracerebral lentiviral gene therapy. EMBO Mol. Med. 2016, 8, 489-510. [CrossRef] [PubMed]

97. Aiuti, A.; Roncarolo, M.G.; Naldini, L. Gene therapy for ADA-SCID, the first marketing approval of an ex vivo gene therapy in Europe: Paving the road for the next generation of advanced therapy medicinal products. EMBO Mol. Med. 2017, 9, 737-740. [CrossRef] [PubMed]

98. Sakthiswary, R.; Raymond, A.A. Stem cell therapy in neurodegenerative diseases: From principles to practice. Neural Regen. Res. 2012, 7, 1822. [PubMed]

99. Goswami, R.; Subramanian, G.; Silayeva, L.; Newkirk, I.; Doctor, D.; Chawla, K.; Chattopadhyay, S.; Chandra, D.; Chilukuri, N.; Betapudi, V. Gene therapy leaves a vicious cycle. Front. Oncol. 2019, 9, 297. [CrossRef] [PubMed]

100. Zhang, H.X.; Zhang, Y.; Yin, H. Genome Editing with mRNA Encoding ZFN, TALEN, and Cas9. Mol. Ther. 2019, 27, 735-746. [CrossRef] [PubMed]

101. Gene-Editing Could Modify and Cure Disease: CRISPR vs. TALENs. Available online: https://ark-invest. com/research/crispr-vs-talens (accessed on 4 December 2019).

102. Razzouk, S. CRISPR-Cas9: A cornerstone for the evolution of precision medicine. Ann. Hum. Genet. 2018, 82, 331-357. [CrossRef] [PubMed]

103. Knott, G.J.; Doudna, J.A. CRISPR-Cas guides the future of genetic engineering. Science 2018, 361, 866-869. [CrossRef]

104. Jinek, M.; Chylinski, K.; Fonfara, I.; Hauer, M.; Doudna, J.A.; Charpentier, E. A programmable dual-RNA-guided DNA endonuclease in adaptive bacterial immunity. Science 2012, 337, 816-821. [CrossRef]

105. Anders, C.; Niewoehner, O.; Duerst, A.; Jinek, M. Structural basis of PAM-dependent target DNA recognition by the Cas9 endonuclease. Nature 2014, 513, 569-573. [CrossRef]

106. Rath, D.; Amlinger, L.; Rath, A.; Lundgren, M. The CRISPR-Cas immune system: Biology, mechanisms and applications. Biochimie 2015, 117, 119-128. [CrossRef]

107. Aach, J.; Mali, P.; Church, G.M. CasFinder: Flexible Algorithm for Identifying Specific Cas9 Targets in Genomes. bioRxiv 2014, 005074.

108. Montague, T.G.; Cruz, J.M.; Gagnon, J.A.; Church, G.M.; Valen, E. CHOPCHOP: A CRISPR/Cas9 and TALEN web tool for genome editing. Nucleic Acids Res. 2014, 42, W401-W407. [CrossRef] [PubMed]

109. Liu, H.; Wei, Z.; Dominguez, A.; Li, Y.; Wang, X.; Qi, L.S. CRISPR-ERA: A comprehensive design tool for CRISPR-mediated gene editing, repression and activation. Bioinformatics 2015, 31, 3676-3678. [CrossRef] [PubMed] 
110. Ma, J.; Köster, J.; Qin, Q.; Hu, S.; Li, W.; Chen, C.; Cao, Q.; Wang, J.; Mei, S.; Liu, Q.; et al. CRISPR-DO for genome-wide CRISPR design and optimization. Bioinformatics 2016, 32, 3336-3338. [CrossRef]

111. Perez, A.R.; Pritykin, Y.; Vidigal, J.A.; Chhangawala, S.; Zamparo, L.; Leslie, C.S.; Ventura, A. GuideScan software for improved single and paired CRISPR guide RNA design. Nat. Biotechnol. 2017, 35, 347-349. [CrossRef]

112. Sunagawa, G.A.; Sumiyama, K.; Ukai-Tadenuma, M.; Perrin, D.; Fujishima, H.; Ukai, H.; Nishimura, O.; Shi, S.; Ohno, R.I.; Narumi, R.; et al. Mammalian Reverse Genetics without Crossing Reveals Nr3a as a Short-Sleeper Gene. Cell Rep. 2016, 14, 662-677. [CrossRef]

113. Morena, F.; Armentano, I.; Montanucci, P.; Argentati, C.; Fortunati, E.; Montesano, S.; Bicchi, I.; Pescara, T.; Pennoni, I.; Mattioli, S.; et al. Design of a nanocomposite substrate inducing adult stem cell assembly and progression toward an Epiblast-like or Primitive Endoderm-like phenotype via mechanotransduction. Biomaterials 2017, 144, 211-229. [CrossRef]

114. Caplan, A.I. Tissue Engineering: Then, Now, and the Future. Tissue Eng. Part A 2019, 25, 515-517. [CrossRef]

115. Williams, D.F. Challenges With the Development of Biomaterials for Sustainable Tissue Engineering. Front. Bioeng. Biotechnol. 2019, 7, 127. [CrossRef]

116. Argentati, C.; Morena, F.; Montanucci, P.; Rallini, M.; Basta, G.; Calabrese, N.; Calafiore, R.; Cordellini, M.; Emiliani, C.; Armentano, I.; et al. Surface hydrophilicity of poly(L-lactide) acid polymer film changes the human adult adipose stem cell architecture. Polymers 2018, 10, 140. [CrossRef]

117. Chen, F.M.; Liu, X. Advancing biomaterials of human origin for tissue engineering. Prog. Polym. Sci. 2016, 53, 86-168. [CrossRef] [PubMed]

118. Morena, F.; Argentati, C.; Calzoni, E.; Cordellini, M.; Emiliani, C.; D’Angelo, F.; Martino, S. Ex-vivo tissues engineering modeling for reconstructive surgery using human adult adipose stem cells and polymeric nanostructured matrix. Nanomaterials 2016, 6, 57. [CrossRef] [PubMed]

119. Tarpani, L.; Morena, F.; Gambucci, M.; Zampini, G.; Massaro, G.; Argentati, C.; Emiliani, C.; Martino, S.; Latterini, L. The influence of modified silica nanomaterials on adult stem cell culture. Nanomaterials 2016, 6, 104. [CrossRef]

120. Mani, M.P.; Jaganathan, S.K.; Md Khudzari, A.Z.; Ismail, A.F. Green synthesis of nickel oxide particles and its integration into polyurethane scaffold matrix ornamented with groundnut oil for bone tissue engineering. Int. J. Polym. Anal. Charact. 2019, 24, 571-583. [CrossRef]

121. Hayoun-Neeman, D.; Korover, N.; Etzion, S.; Ofir, R.; Lichtenstein, R.G.; Cohen, S. Exploring peptide-functionalized alginate scaffolds for engineering cardiac tissue from human embryonic stem cell-derived cardiomyocytes in serum-free medium. Polym. Adv. Technol. 2019, 30, 2493-2505. [CrossRef]

122. Armentano, I.; Puglia, D.; Luzi, F.; Arciola, C.R.; Morena, F.; Martino, S.; Torre, L. Nanocomposites based on biodegradable polymers. Materials 2018, 11, 795. [CrossRef]

123. Armentano, I.; Tarpani, L.; Morena, F.; Martino, S.; Latterini, L.; Torre, L. Nanostructured Biopolymer-based Materials for Regenerative Medicine Applications. Curr. Org. Chem. 2018, 22, 1193-1204. [CrossRef]

124. Jansen, K.A.; Donato, D.M.; Balcioglu, H.E.; Schmidt, T.; Danen, E.H.J.; Koenderink, G.H. A guide to mechanobiology: Where biology and physics meet. Biochim. Biophys. Acta Mol. Cell Res. 2015, 1853, 3043-3052. [CrossRef]

125. Aguado, B.A.; Grim, J.C.; Rosales, A.M.; Watson-Capps, J.J.; Anseth, K.S. Engineering precision biomaterials for personalized medicine. Sci. Transl. Med. 2018, 10, eaam8645. [CrossRef]

126. Abou-El-Enein, M.; Elsanhoury, A.; Reinke, P. Overcoming Challenges Facing Advanced Therapies in the EU Market. Cell Stem Cell 2016, 19, 293-297. [CrossRef]

127. Hart, C.E.; Loewen-Rodriguez, A.; Lessem, J. Dermagraft: Use in the Treatment of Chronic Wounds. Adv. Wound Care 2012, 1, 138-141. [CrossRef] [PubMed]

128. Kreuz, P.C.; Kalkreuth, R.H.; Niemeyer, P.; Uhl, M.; Erggelet, C. Long-Term Clinical and MRI Results of Matrix-Assisted Autologous Chondrocyte Implantation for Articular Cartilage Defects of the Knee. Cartilage 2019, 10, 305-313. [CrossRef]

129. Epicel (cultured epidermal autografts) | FDA. Available online: https://www.fda.gov/vaccines-bloodbiologics/approved-blood-products/epicel-cultured-epidermal-autografts (accessed on 2 December 2019).

130. Varkey, M.; Ding, J.; Tredget, E. Advances in Skin Substitutes-Potential of Tissue Engineered Skin for Facilitating Anti-Fibrotic Healing. J. Funct. Biomater. 2015, 6, 547-563. [CrossRef] [PubMed] 
131. Pellegrini, G.; Ardigò, D.; Milazzo, G.; Iotti, G.; Guatelli, P.; Pelosi, D.; De Luca, M. Navigating Market Authorization: The Path Holoclar Took to Become the First Stem Cell Product Approved in the European Union. Stem Cells Transl. Med. 2018, 7, 146-154. [CrossRef]

132. Berkowitz, J.J.; Ferkel, R.D. New and emerging techniques in cartilage repair: Matrix-induced autologous chondrocyte implantation (MACI). In Sports Injuries of the Foot and Ankle: A Focus on Advanced Surgical Techniques; Springer: Berlin/Heidelberg, Germany, 2019; pp. 125-131. ISBN 9783662587041.

133. Hoburg, A.; Löer, I.; Körsmeier, K.; Siebold, R.; Niemeyer, P.; Fickert, S.; Ruhnau, K. Matrix-Associated Autologous Chondrocyte Implantation Is an Effective Treatment at Midterm Follow-up in Adolescents and Young Adults. Orthop. J. Sports Med. 2019, 7. [CrossRef]

134. Spherox | European Medicines Agency. Available online: https://www.ema.europa.eu/en/medicines/human/ EPAR/spherox (accessed on 2 December 2019).

135. Murphy, S.V.; Atala, A. 3D bioprinting of tissues and organs. Nat. Biotechnol. 2014, 32, 773-785. [CrossRef] [PubMed]

136. Jammalamadaka, U.; Tappa, K. Recent advances in biomaterials for 3D printing and tissue engineering. J. Funct. Biomater. 2018, 9, 22. [CrossRef] [PubMed]

137. Cui, H.; Zhu, W.; Holmes, B.; Zhang, L.G. Biologically Inspired Smart Release System Based on 3D Bioprinted Perfused Scaffold for Vascularized Tissue Regeneration. Adv. Sci. 2016, 3, 1600058. [CrossRef]

138. Albritton, J.L.; Miller, J.S. 3D bioprinting: Improving in vitro models of metastasis with heterogeneous tumor microenvironments. DMM Dis. Model. Mech. 2017, 10, 3-14. [CrossRef]

139. Xu, F.; Celli, J.; Rizvi, I.; Moon, S.; Hasan, T.; Demirci, U. A three-dimensional in vitro ovarian cancer coculture model using a high-throughput cell patterning platform. Biotechnol. J. 2011, 6, 204-212. [CrossRef]

140. Ma, X.; Liu, J.; Zhu, W.; Tang, M.; Lawrence, N.; Yu, C.; Gou, M.; Chen, S. 3D bioprinting of functional tissue models for personalized drug screening and in vitro disease modeling. Adv. Drug Deliv. Rev. 2018, 132, 235-251. [CrossRef] [PubMed]

141. Murphy, S.V.; De Coppi, P.; Atala, A. Opportunities and challenges of translational 3D bioprinting. Nat. Biomed. Eng. 2019, 2019, 1-11. [CrossRef] [PubMed]

142. Lancaster, M.A.; Huch, M. Disease modelling in human organoids. DMM Dis. Model. Mech. 2019, 12, dmm039347. [CrossRef] [PubMed]

143. Shen, H. Organoids have opened avenues into investigating numerous diseases. But how well do they mimic the real thing? Proc. Natl. Acad. Sci. USA 2018, 115, 3507-3509. [CrossRef] [PubMed]

144. Takahashi, T. Organoids for Drug Discovery and Personalized Medicine. Annu. Rev. Pharmacol. Toxicol. 2019, 59, 447-462. [CrossRef]

145. Lehmann, R.; Lee, C.M.; Shugart, E.C.; Benedetti, M.; Charo, R.A.; Gartner, Z.; Hogan, B.; Knoblich, J.; Nelson, C.M.; Wilson, K.M. Human organoids: A new dimension in cell biology. Mol. Biol. Cell 2019, 30, 1129-1137. [CrossRef]

146. Sato, T.; Vries, R.G.; Snippert, H.J.; Van De Wetering, M.; Barker, N.; Stange, D.E.; Van Es, J.H.; Abo, A.; Kujala, P.; Peters, P.J.; et al. Single Lgr5 stem cells build crypt-villus structures in vitro without a mesenchymal niche. Nature 2009, 459, 262-265. [CrossRef]

147. Yu, F.; Hunziker, W.; Choudhury, D. Engineering microfluidic organoid-on-a-chip platforms. Micromachines 2019, 10, 165. [CrossRef]

148. Brassard, J.A.; Lutolf, M.P. Engineering Stem Cell Self-organization to Build Better Organoids. Cell Stem Cell 2019, 24, 860-876. [CrossRef]

149. Kaushik, G.; Ponnusamy, M.P.; Batra, S.K. Concise Review: Current Status of Three-Dimensional Organoids as Preclinical Models. Stem Cells 2018, 36, 1329-1340. [CrossRef]

150. Lee, S.H.; Hu, W.; Matulay, J.T.; Silva, M.V.; Owczarek, T.B.; Kim, K.; Chua, C.W.; Barlow, L.M.J.; Kandoth, C.; Williams, A.B.; et al. Tumor Evolution and Drug Response in Patient-Derived Organoid Models of Bladder Cancer. Cell 2018, 173, 515-528. [CrossRef] [PubMed]

151. Mullenders, J.; de Jongh, E.; Brousali, A.; Roosen, M.; Blom, J.P.A.; Begthel, H.; Korving, J.; Jonges, T.; Kranenburg, O.; Meijer, R.; et al. Mouse and human urothelial cancer organoids: A tool for bladder cancer research. Proc. Natl. Acad. Sci. USA 2019, 116, 4567-4574. [CrossRef] [PubMed]

152. Wimmer, R.A.; Leopoldi, A.; Aichinger, M.; Wick, N.; Hantusch, B.; Novatchkova, M.; Taubenschmid, J.; Hämmerle, M.; Esk, C.; Bagley, J.A.; et al. Human blood vessel organoids as a model of diabetic vasculopathy. Nature 2019, 565, 505-510. [CrossRef] [PubMed] 
153. Lancaster, M.A.; Renner, M.; Martin, C.A.; Wenzel, D.; Bicknell, L.S.; Hurles, M.E.; Homfray, T.; Penninger, J.M.; Jackson, A.P.; Knoblich, J.A. Cerebral organoids model human brain development and microcephaly. Nature 2013, 501, 373-379. [CrossRef]

154. Mariani, J.; Coppola, G.; Zhang, P.; Abyzov, A.; Provini, L.; Tomasini, L.; Amenduni, M.; Szekely, A.; Palejev, D.; Wilson, M.; et al. FOXG1-Dependent Dysregulation of GABA/Glutamate Neuron Differentiation in Autism Spectrum Disorders. Cell 2015, 162, 375-390. [CrossRef]

155. Xu, M.; Lee, E.M.; Wen, Z.; Cheng, Y.; Huang, W.K.; Qian, X.; Tcw, J.; Kouznetsova, J.; Ogden, S.C.; Hammack, C.; et al. Identification of small-molecule inhibitors of Zika virus infection and induced neural cell death via a drug repurposing screen. Nat. Med. 2016, 22, 1101-1107. [CrossRef]

156. Raja, W.K.; Mungenast, A.E.; Lin, Y.T.; Ko, T.; Abdurrob, F.; Seo, J.; Tsai, L.H. Self-organizing 3D human neural tissue derived from induced pluripotent stem cells recapitulate Alzheimer's disease phenotypes. PLoS ONE 2016, 11, e0161969. [CrossRef]

157. Moslem, M.; Olive, J.; Falk, A. Stem cell models of schizophrenia, what have we learned and what is the potential? Schizophr. Res. 2019, 210,3-12. [CrossRef]

158. Schwamborn, J.C. Is Parkinson's disease a neurodevelopmental disorder and will brain organoids help us to understand it? Stem Cells Dev. 2018, 27, 968-975. [CrossRef]

159. Yan, Y.; Song, L.; Bejoy, J.; Zhao, J.; Kanekiyo, T.; Bu, G.; Zhou, Y.; Li, Y. Modeling neurodegenerative microenvironment using cortical organoids derived from human stem cells. Tissue Eng. Part A 2018, 24, 1125-1137. [CrossRef]

160. Iefremova, V.; Manikakis, G.; Krefft, O.; Jabali, A.; Weynans, K.; Wilkens, R.; Marsoner, F.; Brändl, B.; Müller, F.J.; Koch, P.; et al. An Organoid-Based Model of Cortical Development Identifies Non-Cell-Autonomous Defects in Wnt Signaling Contributing to Miller-Dieker Syndrome. Cell Rep. 2017, 19, 50-59. [CrossRef] [PubMed]

161. Bershteyn, M.; Nowakowski, T.J.; Pollen, A.A.; Di Lullo, E.; Nene, A.; Wynshaw-Boris, A.; Kriegstein, A.R. Human iPSC-Derived Cerebral Organoids Model Cellular Features of Lissencephaly and Reveal Prolonged Mitosis of Outer Radial Glia. Cell Stem Cell 2017, 20, 435-449. [CrossRef] [PubMed]

162. Hubert, C.G.; Rivera, M.; Spangler, L.C.; Wu, Q.; Mack, S.C.; Prager, B.C.; Couce, M.; McLendon, R.E.; Sloan, A.E.; Rich, J.N. A three-dimensional organoid culture system derived from human glioblastomas recapitulates the hypoxic gradients and cancer stem cell heterogeneity of tumors found in vivo. Cancer Res. 2016, 76, 2465-2477. [CrossRef]

163. Garcez, P.P.; Loiola, E.C.; Da Costa, R.M.; Higa, L.M.; Trindade, P.; Delvecchio, R.; Nascimento, J.M.; Brindeiro, R.; Tanuri, A.; Rehen, S.K. Zika virus: Zika virus impairs growth in human neurospheres and brain organoids. Science 2016, 352, 816-818. [CrossRef]

164. Cugola, F.R.; Fernandes, I.R.; Russo, F.B.; Freitas, B.C.; Dias, J.L.M.; Guimarães, K.P.; Benazzato, C.; Almeida, N.; Pignatari, G.C.; Romero, S.; et al. The Brazilian Zika virus strain causes birth defects in experimental models. Nature 2016, 534, 267-271. [CrossRef]

165. Qian, X.; Nguyen, H.N.; Song, M.M.; Hadiono, C.; Ogden, S.C.; Hammack, C.; Yao, B.; Hamersky, G.R.; Jacob, F.; Zhong, C.; et al. Brain-Region-Specific Organoids Using Mini-bioreactors for Modeling ZIKV Exposure. Cell 2016, 165, 1238-1254. [CrossRef]

166. Watanabe, M.; Buth, J.E.; Vishlaghi, N.; de la Torre-Ubieta, L.; Taxidis, J.; Khakh, B.S.; Coppola, G.; Pearson, C.A.; Yamauchi, K.; Gong, D.; et al. Self-Organized Cerebral Organoids with Human-Specific Features Predict Effective Drugs to Combat Zika Virus Infection. Cell Rep. 2017, 21, 517-532. [CrossRef]

167. Sacramento, C.Q.; De Melo, G.R.; De Freitas, C.S.; Rocha, N.; Hoelz, L.V.B.; Miranda, M.; Fintelman-Rodrigues, N.; Marttorelli, A.; Ferreira, A.C.; Barbosa-Lima, G.; et al. The clinically approved antiviral drug sofosbuvir inhibits Zika virus replication. Sci. Rep. 2017, 7, 40920. [CrossRef]

168. Sachs, N.; de Ligt, J.; Kopper, O.; Gogola, E.; Bounova, G.; Weeber, F.; Balgobind, A.V.; Wind, K.; Gracanin, A.; Begthel, H.; et al. A Living Biobank of Breast Cancer Organoids Captures Disease Heterogeneity. Cell 2018, 172, 373-386. [CrossRef]

169. Van De Wetering, M.; Francies, H.E.; Francis, J.M.; Bounova, G.; Iorio, F.; Pronk, A.; Van Houdt, W.; Van Gorp, J.; Taylor-Weiner, A.; Kester, L.; et al. Prospective derivation of a living organoid biobank of colorectal cancer patients. Cell 2015, 161, 933-945. [CrossRef]

170. Turco, M.Y.; Gardner, L.; Hughes, J.; Cindrova-Davies, T.; Gomez, M.J.; Farrell, L.; Hollinshead, M.; Marsh, S.G.E.; Brosens, J.J.; Critchley, H.O.; et al. Long-term, hormone-responsive organoid cultures of human endometrium in a chemically defined medium. Nat. Cell Biol. 2017, 19, 568-577. [CrossRef] [PubMed] 
171. Boretto, M.; Maenhoudt, N.; Luo, X.; Hennes, A.; Boeckx, B.; Bui, B.; Heremans, R.; Perneel, L.; Kobayashi, H.; Van Zundert, I.; et al. Patient-derived organoids from endometrial disease capture clinical heterogeneity and are amenable to drug screening. Nat. Cell Biol. 2019, 21, 1041-1051. [CrossRef] [PubMed]

172. Li, X.; Francies, H.E.; Secrier, M.; Perner, J.; Miremadi, A.; Galeano-Dalmau, N.; Barendt, W.J.; Letchford, L.; Leyden, G.M.; Goffin, E.K.; et al. Organoid cultures recapitulate esophageal adenocarcinoma heterogeneity providing a model for clonality studies and precision therapeutics. Nat. Commun. 2018, 9, 1-13. [CrossRef]

173. Nugraha, B.; Buono, M.F.; von Boehmer, L.; Hoerstrup, S.P.; Emmert, M.Y. Human Cardiac Organoids for Disease Modeling. Clin. Pharmacol. Ther. 2019, 105, 79-85. [CrossRef]

174. Voges, H.K.; Mills, R.J.; Elliott, D.A.; Parton, R.G.; Porrello, E.R.; Hudson, J.E. Development of a human cardiac organoid injury model reveals innate regenerative potential. Development 2017, 144, 1118-1127. [CrossRef]

175. Nugraha, B.; Buono, M.F.; Emmert, M.Y. Modelling human cardiac diseases with 3D organoid. Eur. Heart J. 2018, 39, 4234-4237. [CrossRef]

176. Dekkers, J.F.; Wiegerinck, C.L.; De Jonge, H.R.; Bronsveld, I.; Janssens, H.M.; De Winter-De Groot, K.M.; Brandsma, A.M.; De Jong, N.W.M.; Bijvelds, M.J.C.; Scholte, B.J.; et al. A functional CFTR assay using primary cystic fibrosis intestinal organoids. Nat. Med. 2013, 19, 939-945. [CrossRef]

177. Ettayebi, K.; Crawford, S.E.; Murakami, K.; Broughman, J.R.; Karandikar, U.; Tenge, V.R.; Neill, F.H.; Blutt, S.E.; Zeng, X.L.; Qu, L.; et al. Replication of human noroviruses in stem cell-derived human enteroids. Science 2016, 353, 1387-1393. [CrossRef]

178. Saxena, K.; Blutt, S.E.; Ettayebi, K.; Zeng, X.-L.; Broughman, J.R.; Crawford, S.E.; Karandikar, U.C.; Sastri, N.P.; Conner, M.E.; Opekun, A.R.; et al. Human Intestinal Enteroids: A New Model To Study Human Rotavirus Infection, Host Restriction, and Pathophysiology. J. Virol. 2016, 90, 43-56. [CrossRef]

179. Heo, I.; Dutta, D.; Schaefer, D.A.; Iakobachvili, N.; Artegiani, B.; Sachs, N.; Boonekamp, K.E.; Bowden, G.; Hendrickx, A.P.A.; Willems, R.J.L.; et al. Modelling Cryptosporidium infection in human small intestinal and lung organoids. Nat. Microbiol. 2018, 3, 814-823. [CrossRef]

180. Zhou, J.; Li, C.; Zhao, G.; Chu, H.; Wang, D.; Yan, H.H.N.; Poon, V.K.M.; Wen, L.; Wong, B.H.Y.; Zhao, X.; et al. Human intestinal tract serves as an alternative infection route for Middle East respiratory syndrome coronavirus. Sci. Adv. 2017, 3, eaao4966. [CrossRef] [PubMed]

181. Forbes, T.A.; Howden, S.E.; Lawlor, K.; Phipson, B.; Maksimovic, J.; Hale, L.; Wilson, S.; Quinlan, C.; Ho, G.; Holman, K.; et al. Patient-iPSC-Derived Kidney Organoids Show Functional Validation of a Ciliopathic Renal Phenotype and Reveal Underlying Pathogenetic Mechanisms. Am. J. Hum. Genet. 2018, 102, 816-831. [CrossRef] [PubMed]

182. Huch, M.; Gehart, H.; Van Boxtel, R.; Hamer, K.; Blokzijl, F.; Verstegen, M.M.A.; Ellis, E.; Van Wenum, M.; Fuchs, S.A.; De Ligt, J.; et al. Long-term culture of genome-stable bipotent stem cells from adult human liver. Cell 2015, 160, 299-312. [CrossRef] [PubMed]

183. Broutier, L.; Mastrogiovanni, G.; Verstegen, M.M.A.; Francies, H.E.; Gavarró, L.M.; Bradshaw, C.R.; Allen, G.E.; Arnes-Benito, R.; Sidorova, O.; Gaspersz, M.P.; et al. Human primary liver cancer-derived organoid cultures for disease modeling and drug screening. Nat. Med. 2017, 23, 1424-1435. [CrossRef]

184. Nie, Y.Z.; Zheng, Y.W.; Miyakawa, K.; Murata, S.; Zhang, R.R.; Sekine, K.; Ueno, Y.; Takebe, T.; Wakita, T.; Ryo, A.; et al. Recapitulation of hepatitis B virus-host interactions in liver organoids from human induced pluripotent stem cells. EBioMedicine 2018, 35, 114-123. [CrossRef]

185. Wang, W.; Wang, Y.; Qu, C.; Wang, S.; Zhou, J.; Cao, W.; Xu, L.; Ma, B.; Hakim, M.S.; Yin, Y.; et al. The RNA genome of hepatitis E virus robustly triggers an antiviral interferon response. Hepatology 2018, 67, 2096-2112. [CrossRef]

186. Sachs, N.; Papaspyropoulos, A.; Zomer-van Ommen, D.D.; Heo, I.; Böttinger, L.; Klay, D.; Weeber, F.; Huelsz-Prince, G.; Iakobachvili, N.; Amatngalim, G.D.; et al. Long-term expanding human airway organoids for disease modeling. EMBO J. 2019, 38, e100300. [CrossRef]

187. Zhou, J.; Li, C.; Sachs, N.; Chiu, M.C.; Wong, B.H.Y.; Chu, H.; Poon, V.K.M.; Wang, D.; Zhao, X.; Wen, L.; et al. Differentiated human airway organoids to assess infectivity of emerging influenza virus. Proc. Natl. Acad. Sci. USA 2018, 115, 6822-6827. [CrossRef]

188. Chen, Y.W.; Huang, S.X.; De Carvalho, A.L.R.T.; Ho, S.H.; Islam, M.N.; Volpi, S.; Notarangelo, L.D.; Ciancanelli, M.; Casanova, J.L.; Bhattacharya, J.; et al. A three-dimensional model of human lung development and disease from pluripotent stem cells. Nat. Cell Biol. 2017, 19, 542-549. [CrossRef] 
189. Boj, S.F.; Hwang, C.I.; Baker, L.A.; Chio, I.I.C.; Engle, D.D.; Corbo, V.; Jager, M.; Ponz-Sarvise, M.; Tiriac, H.; Spector, M.S.; et al. Organoid models of human and mouse ductal pancreatic cancer. Cell 2015, 160, 324-338. [CrossRef]

190. Seino, T.; Kawasaki, S.; Shimokawa, M.; Tamagawa, H.; Toshimitsu, K.; Fujii, M.; Ohta, Y.; Matano, M.; Nanki, K.; Kawasaki, K.; et al. Human Pancreatic Tumor Organoids Reveal Loss of Stem Cell Niche Factor Dependence during Disease Progression. Cell Stem Cell 2018, 22, 454-467. [CrossRef] [PubMed]

191. Tiriac, H.; Bucobo, J.C.; Tzimas, D.; Grewel, S.; Lacomb, J.F.; Rowehl, L.M.; Nagula, S.; Wu, M.; Kim, J.; Sasson, A.; et al. Successful creation of pancreatic cancer organoids by means of EUS-guided fine-needle biopsy sampling for personalized cancer treatment. Gastrointest. Endosc. 2018, 87, 1474-1480. [CrossRef] [PubMed]

192. Gao, D.; Vela, I.; Sboner, A.; Iaquinta, P.J.; Karthaus, W.R.; Gopalan, A.; Dowling, C.; Wanjala, J.N.; Undvall, E.A.; Arora, V.K.; et al. Organoid cultures derived from patients with advanced prostate cancer. Cell 2014, 159, 176-187. [CrossRef] [PubMed]

193. Parfitt, D.A.; Lane, A.; Ramsden, C.M.; Carr, A.J.F.; Munro, P.M.; Jovanovic, K.; Schwarz, N.; Kanuga, N.; Muthiah, M.N.; Hull, S.; et al. Identification and Correction of Mechanisms Underlying Inherited Blindness in Human iPSC-Derived Optic Cups. Cell Stem Cell 2016, 18, 769-781. [CrossRef]

194. Yan, H.H.N.; Siu, H.C.; Law, S.; Ho, S.L.; Yue, S.S.K.; Tsui, W.Y.; Chan, D.; Chan, A.S.; Ma, S.; Lam, K.O.; et al. A Comprehensive Human Gastric Cancer Organoid Biobank Captures Tumor Subtype Heterogeneity and Enables Therapeutic Screening. Cell Stem Cell 2018, 23, 882-897. [CrossRef]

195. Seidlitz, T.; Merker, S.R.; Rothe, A.; Zakrzewski, F.; Von Neubeck, C.; Grützmann, K.; Sommer, U.; Schweitzer, C.; Schölch, S.; Uhlemann, H.; et al. Human gastric cancer modelling using organoids. Gut 2019, 68, 207-217. [CrossRef]

196. Bartfeld, S.; Bayram, T.; Van De Wetering, M.; Huch, M.; Begthel, H.; Kujala, P.; Vries, R.; Peters, P.J.; Clevers, H. In vitro expansion of human gastric epithelial stem cells and their responses to bacterial infection. Gastroenterology 2015, 148, 126-136. [CrossRef]

197. McCracken, K.W.; Catá, E.M.; Crawford, C.M.; Sinagoga, K.L.; Schumacher, M.; Rockich, B.E.; Tsai, Y.H.; Mayhew, C.N.; Spence, J.R.; Zavros, Y.; et al. Modelling human development and disease in pluripotent stem-cell-derived gastric organoids. Nature 2014, 516, 400-404. [CrossRef]

198. Sonnen, K.F.; Merten, C.A. Microfluidics as an Emerging Precision Tool in Developmental Biology. Dev. Cell 2019, 48, 293-311. [CrossRef]

199. Ingber, D.E. Developmentally inspired human 'organs on chips'. Development 2018, 145, dev156125. [CrossRef]

200. Low, L.A.; Tagle, D.A. Organs-on-chips: Progress, challenges, and future directions. Exp. Biol. Med. 2017, 242, 1573-1578. [CrossRef]

201. Gale, B.; Jafek, A.; Lambert, C.; Goenner, B.; Moghimifam, H.; Nze, U.; Kamarapu, S. A Review of Current Methods in Microfluidic Device Fabrication and Future Commercialization Prospects. Inventions 2018, 3, 60. [CrossRef]

202. Sosa-Hernández, J.E.; Villalba-Rodríguez, A.M.; Romero-Castillo, K.D.; Aguilar-Aguila-Isaías, M.A.; García-Reyes, I.E.; Hernández-Antonio, A.; Ahmed, I.; Sharma, A.; Parra-Saldívar, R.; Iqbal, H.M.N. Organs-on-a-chip module: A review from the development and applications perspective. Micromachines 2018, 9, 536. [CrossRef] [PubMed]

203. Van Den Berg, A.; Mummery, C.L.; Passier, R.; Van der Meer, A.D. Personalised organs-on-chips: Functional testing for precision medicine. Lab Chip 2019, 19, 198-205. [CrossRef]

204. Brown, J.A.; Codreanu, S.G.; Shi, M.; Sherrod, S.D.; Markov, D.A.; Neely, M.D.; Britt, C.M.; Hoilett, O.S.; Reiserer, R.S.; Samson, P.C.; et al. Metabolic consequences of inflammatory disruption of the blood-brain barrier in an organ-on-chip model of the human neurovascular unit. J. Neuroinflamm. 2016, 13, 306. [CrossRef] [PubMed]

205. Yang, X.; Li, K.; Zhang, X.; Liu, C.; Guo, B.; Wen, W.; Gao, X. Nanofiber membrane supported lung-on-a-chip microdevice for anti-cancer drug testing. Lab Chip 2018, 18, 486-495. [CrossRef]

206. Bauer, S.; Wennberg Huldt, C.; Kanebratt, K.P.; Durieux, I.; Gunne, D.; Andersson, S.; Ewart, L.; Haynes, W.G.; Maschmeyer, I.; Winter, A.; et al. Functional coupling of human pancreatic islets and liver spheroids on-a-chip: Towards a novel human ex vivo type 2 diabetes model. Sci. Rep. 2017, 7, 1-11. [CrossRef] 
207. Coppeta, J.R.; Mescher, M.J.; Isenberg, B.C.; Spencer, A.J.; Kim, E.S.; Lever, A.R.; Mulhern, T.J.; Prantil-Baun, R.; Comolli, J.C.; Borenstein, J.T. A portable and reconfigurable multi-organ platform for drug development with onboard microfluidic flow control. Lab Chip 2017, 17, 134-144. [CrossRef]

208. Park, S.E.; Georgescu, A.; Huh, D. Organoids-on-a-chip. Science 2019, 364, 960-965. [CrossRef]

209. Park, J.; Wetzel, I.; Marriott, I.; Dréau, D.; D'Avanzo, C.; Kim, D.Y.; Tanzi, R.E.; Cho, H. A 3D human triculture system modeling neurodegeneration and neuroinflammation in Alzheimer's disease. Nat. Neurosci. 2018, 21, 941-951. [CrossRef]

210. Herland, A.; van der Meer, A.D.; FitzGerald, E.A.; Park, T.-E.; Sleeboom, J.J.F.; Ingber, D.E. Distinct Contributions of Astrocytes and Pericytes to Neuroinflammation Identified in a 3D Human Blood-Brain Barrier on a Chip. PLoS ONE 2016, 11, e0150360. [CrossRef] [PubMed]

211. Fan, Y.; Nguyen, D.T.; Akay, Y.; Xu, F.; Akay, M. Engineering a Brain Cancer Chip for High-throughput Drug Screening. Sci. Rep. 2016, 6, 25062. [CrossRef]

212. van der Helm, M.W.; van der Meer, A.D.; Eijkel, J.C.T.; van den Berg, A.; Segerink, L.I. Microfluidic organ-on-chip technology for blood-brain barrier research. Tissue Barriers 2016, 4, e1142493. [CrossRef] [PubMed]

213. Wang, G.; McCain, M.L.; Yang, L.; He, A.; Pasqualini, F.S.; Agarwal, A.; Yuan, H.; Jiang, D.; Zhang, D.; Zangi, L.; et al. Modeling the mitochondrial cardiomyopathy of Barth syndrome with induced pluripotent stem cell and heart-on-chip technologies. Nat. Med. 2014, 20, 616-623. [CrossRef]

214. Ugolini, G.S.; Visone, R.; Cruz-Moreira, D.; Mainardi, A.; Rasponi, M. Generation of functional cardiac microtissues in a beating heart-on-a-chip. In Methods in Cell Biology; Academic Press Inc.: New York, NY, USA, 2018; pp. 69-84. ISBN 9780128142806.

215. Nunes, S.S.; Feric, N.; Pahnke, A.; Miklas, J.W.; Li, M.; Coles, J.; Gagliardi, M.; Keller, G.; Radisic, M. Human Stem Cell-Derived Cardiac Model of Chronic Drug Exposure. ACS Biomater. Sci. Eng. 2017, 3, 1911-1921. [CrossRef]

216. Weber, E.J.; Lidberg, K.A.; Wang, L.; Bammler, T.K.; MacDonald, J.W.; Li, M.J.; Redhair, M.; Atkins, W.M.; Tran, C.; Hines, K.M.; et al. Human kidney on a chip assessment of polymyxin antibiotic nephrotoxicity. JCI Insight 2018, 3, 123673. [CrossRef]

217. Ortega-Prieto, A.M.; Skelton, J.K.; Wai, S.N.; Large, E.; Lussignol, M.; Vizcay-Barrena, G.; Hughes, D.; Fleck, R.A.; Thursz, M.; Catanese, M.T.; et al. 3D microfluidic liver cultures as a physiological preclinical tool for hepatitis B virus infection. Nat. Commun. 2018, 9, 1-15. [CrossRef]

218. Li, X.; George, S.M.; Vernetti, L.; Gough, A.H.; Taylor, D.L. A glass-based, continuously zonated and vascularized human liver acinus microphysiological system (vLAMPS) designed for experimental modeling of diseases and ADME/TOX. Lab Chip 2018, 18, 2614-2631. [CrossRef]

219. Deng, J.; Zhang, X.; Chen, Z.; Luo, Y.; Lu, Y.; Liu, T.; Wu, Z.; Jin, Y.; Zhao, W.; Lin, B. A cell lines derived microfluidic liver model for investigation of hepatotoxicity induced by drug-drug interaction. Biomicrofluidics 2019, 13, 024101. [CrossRef]

220. Gori, M.; Simonelli, M.C.; Giannitelli, S.M.; Businaro, L.; Trombetta, M.; Rainer, A. Investigating nonalcoholic fatty liver disease in a liver-on-a-chip microfluidic device. PLoS ONE 2016, 11, e0159729. [CrossRef]

221. Deng, J.; Wei, W.; Chen, Z.; Lin, B.; Zhao, W.; Luo, Y.; Zhang, X. Engineered liver-on-a-chip platform to mimic liver functions and its biomedical applications: A review. Micromachines 2019, 10, 676. [CrossRef] [PubMed]

222. Punde, T.H.; Wu, W.H.; Lien, P.C.; Chang, Y.L.; Kuo, P.H.; Chang, M.D.T.; Lee, K.Y.; Huang, C.D.; Kuo, H.P.; Chan, Y.F.; et al. A biologically inspired lung-on-a-chip device for the study of protein-induced lung inflammation. Integr. Biol. 2015, 7, 162-169. [CrossRef] [PubMed]

223. Felder, M.; Trueeb, B.; Stucki, A.O.; Borcard, S.; Stucki, J.D.; Schnyder, B.; Geiser, T.; Guenat, O.T. Impaired wound healing of alveolar lung epithelial cells in a breathing lung-on-a-chip. Front. Bioeng. Biotechnol. 2019, 7, 3. [CrossRef] [PubMed]

(C) 2020 by the authors. Licensee MDPI, Basel, Switzerland. This article is an open access article distributed under the terms and conditions of the Creative Commons Attribution (CC BY) license (http://creativecommons.org/licenses/by/4.0/). 